\title{
REVIEW
}

\section{The microbiology of isoprene cycling in aquatic ecosystems}

\author{
R. A. Dawson ${ }^{1, *}$, A. T. Crombie ${ }^{1}$, P. Pichon ${ }^{2}$, M. Steinke ${ }^{2}$, T. J. McGenity ${ }^{2}$, \\ J. C. Murrell ${ }^{1, *}$ \\ ${ }^{1}$ University of East Anglia, School of Environmental Sciences, Norwich Research Park, Norwich NR4 7TJ, UK \\ ${ }^{2}$ University of Essex, School of Life Sciences, Wivenhoe Park, Colchester CO4 3SQ, UK
}

\begin{abstract}
Isoprene (2-methyl-1,3-butadiene) is emitted in vast quantities (>500 $\mathrm{Tg} \mathrm{C} \mathrm{yr}^{-1}$ ). Most isoprene is emitted by trees, but there is still incomplete understanding of the diversity of isoprene sources. The reactivity of isoprene in the atmosphere has potential implications for both global warming and global cooling, with human health implications also arising from isopreneinduced ozone formation in urban areas. Isoprene emissions from terrestrial environments have been studied for many years, but our understanding of aquatic isoprene emissions is less complete. Several abundant phytoplankton taxa produced isoprene in the laboratory, and the relationship between chlorophyll $a$ and isoprene production has been used to estimate emissions from marine environments. The aims of this review are to highlight the role of aquatic environments in the biological cycling of isoprene and to stimulate further study of isoprene metabolism in marine and freshwater environments. From a microbial ecology perspective, the isoprene metabolic gene cluster, first identified in Rhodococcus sp. AD45 (isoGHIJABCDEF) and subsequently found in every genome-sequenced isoprene-degrader, provides the ideal basis for molecular studies on the distribution and diversity of isoprene-degrading communities. Further investigations of isopreneemitting microbes, such as the influence of environmental factors and geographical location, must also be considered when attempting to constrain estimates of the flux of isoprene in aquatic ecosystems. We also report isoprene emission by the scleractinian coral Acropora horrida and the degradation of isoprene by the same coral holobiont, which highlights the importance of better understanding the cycling of isoprene in marine environments.
\end{abstract}

KEY WORDS: Isoprene $\cdot$ Biogenic volatile organic compounds $\cdot$ BVOC $\cdot$ Phytoplankton $\cdot$ Coral $\cdot$ Marine $\cdot$ Freshwater

\section{INTRODUCTION}

Isoprene is one of the most abundant atmospheric trace gases, and yet, compared to methane, the biogeochemical cycle for isoprene is relatively poorly understood. In particular, comparatively little is known about the biological consumption of isoprene in the biosphere before it enters the atmosphere. Iso-

${ }^{*}$ Corresponding authors: j.c.murrell@uea.ac.uk, and r.dawson@uea.ac.uk prene, like methane, can be a source of carbon and energy for aerobic bacteria (Van Ginkel et al. 1987, van Hylckama Vlieg et al. 2000, Crombie et al. 2015). The majority of isoprene is produced by land plants (Guenther et al. 2006, 2012), but there are many marine and freshwater sources of isoprene. The aims of this review are to summarize what is known about aquatic isoprene cycling and to highlight the poten-

(C) The authors 2021. Open Access under Creative Commons by Attribution Licence. Use, distribution and reproduction are unrestricted. Authors and original publication must be credited. 
tial for further study of the ecology of isoprene-degrading microbes and the biological consumption of isoprene in aquatic environments. Our understanding of the physiology, biochemistry, molecular biology and ecology of isoprene-degrading bacteria has focussed mostly on terrestrial environments (reviewed by McGenity et al. 2018, Carrión et al. 2020b, Murrell et al. 2020), and so we summarise what is known about the biology of isoprene consumption using examples mainly from the terrestrial environment and then focus on aquatic environments.

Isoprene is released into the biosphere at around $500 \mathrm{Tg} \mathrm{C} \mathrm{yr}{ }^{-1}$, a flux approximately equal in magnitude to that of methane in terms of global emissions (Fig. 1) (Atkinson \& Arey 2003, Guenther et al. 2012). Isoprene is highly volatile and reactive, and it has a variety of effects on the Earth's climate depending on the levels of other compounds, including nitrogen oxides, in the atmosphere (Atkinson \& Arey 2003). Isoprene increases the longevity of methane in the atmosphere by reacting with hydroxyl radicals and thus, indirectly, acts as a global warming gas (Collins et al. 2002, Folberth et al. 2006). Oxidation products of isoprene can also promote aerosol formation, leading to increased cloud albedo and global cooling. Reactions of isoprene with atmospheric compounds also affect the levels of ozone in the lower atmosphere (Trainer et al. 1987, Atkinson \& Arey 2003, Carlton et al. 2009). Increased planting of major isoprene-producing crop plants such as oil palm, poplar and willow has stimulated considerable interest in the effects of isoprene on air quality (Sharkey et al. 2008, Hewitt et al. 2009, Karlsson et al. 2020, Monson et al. 2020).

\section{EMISSION OF ISOPRENE FROM TERRESTRIAL ENVIRONMENTS}

The majority (>90\%) of isoprene released into the atmosphere is from terrestrial plants, primarily trees (Fig. 1). Not all trees produce isoprene, and there is still considerable debate as to the exact role of isoprene in species that do produce it. Isoprene is produced from dimethylallyl diphosphate (DMAPP), a precursor molecule for many building blocks of cells including sterols, carotenoids, chlorophyll, quinones and hormones. DMAPP biosynthesis occurs via the mevalonate (MVA) pathway (in animals, fungi, archaea, in a minority of bacteria and in the plant cytosol) or the methylerythritol 4-phosphate (MEP) pathway (in chloroplasts, the major site of isoprene

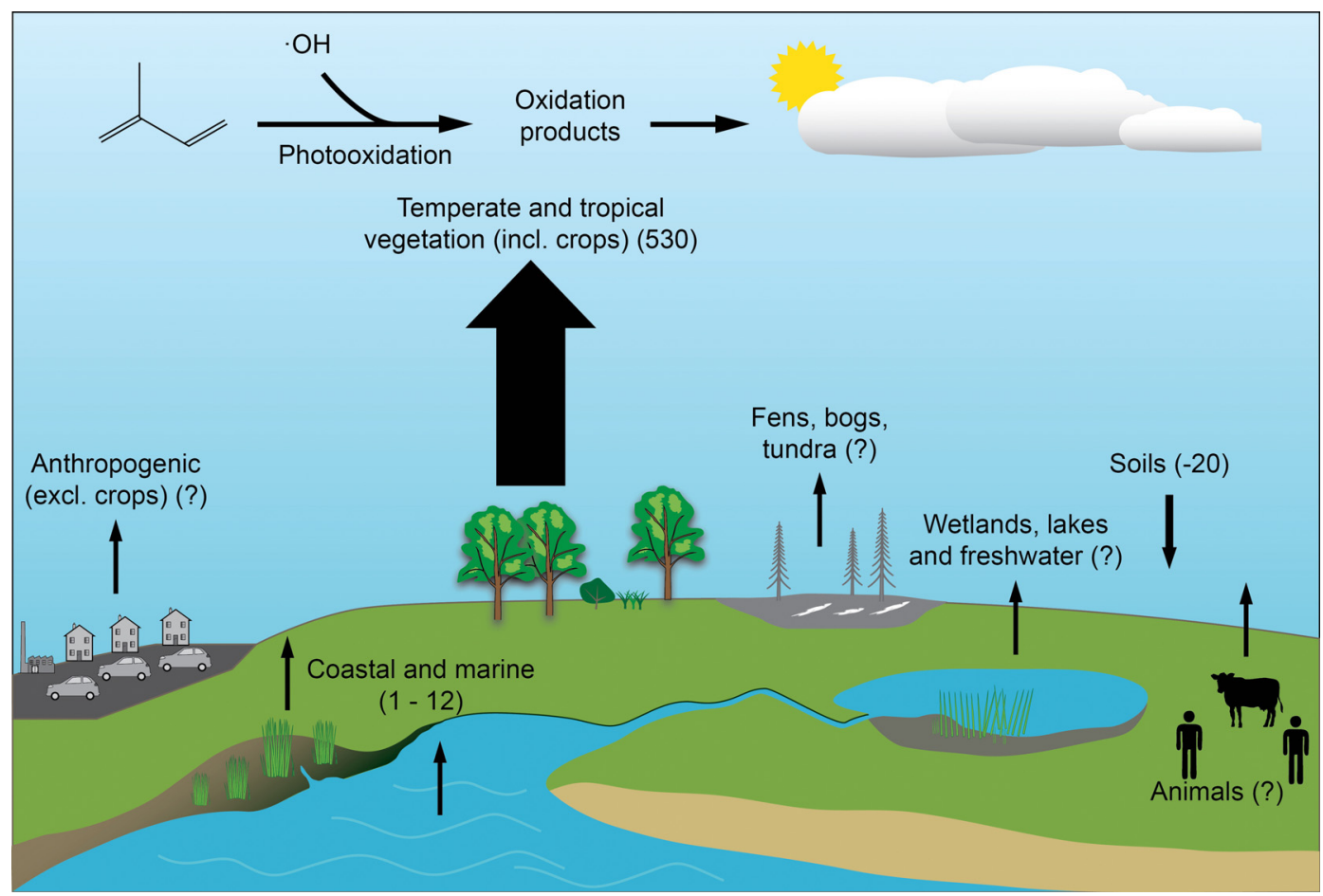

Fig. 1. Estimated annual net fluxes of isoprene from different environments (shown in brackets), both biogenic and anthropogenic, where each component is shown in $\mathrm{Tg} \mathrm{C} \mathrm{yr}^{-1}$ (adapted from Murrell et al. 2020). Where isoprene emissions are poorly constrained, a question mark has been included in place of values for net flux 
production, and also in bacteria) (Rohmer 1999, Zhao et al. 2013). In trees that are substantial producers of isoprene, $1-20 \%$ of the carbon fixed through photosynthesis and the Calvin cycle can be released to the atmosphere as isoprene, mainly via the leaves (Guenther et al. 1995, Harley et al. 1996, Sharkey \& Yeh 2001, Lantz et al. 2019). Isoprene biosynthesis is a costly process in terms of reducing power and energy, and so it represents a substantial metabolic drain on the plant. This metabolic 'bleed' is therefore presumably of significant benefit to plants, and the current dogma is that there are multiple roles for isoprene in protecting the plant from thermal and oxidative stress (Singsaas et al. 1997, Sharkey et al. 2001, Vickers et al. 2009), stabilizing membranes (Velikova et al. 2011), protecting against predation by grazing insects, and acting as a signalling molecule (Lantz et al. 2019, Zuo et al. 2019). These possible roles for isoprene production by plants have been reviewed in detail (Sharkey et al. 2008, Vickers et al. 2009, Lantz et al. 2019). Other sources of isoprene in the biosphere include some bacteria, archaea, fungi, and especially microalgae and macroalgae, which are thought to be the main producers of isoprene in the marine environment, contributing up to around 11.6 Tg C $\mathrm{yr}^{-1}$ (Broadgate et al. 1997, Luo \& Yu 2010, Shaw et al. 2010, Conte et al. 2020). Biological sources of isoprene in wetlands, and freshwater, coastal and marine environments are discussed in Sections 7-10 and detailed in Table 1. Although likely to be small in comparison with biological sources, anthropogenic isoprene emissions may be important in urban areas. Vehicle exhaust is likely to be a large anthropogenic source of isoprene (Reimann et al. 2000, Khan et al. 2018), although no definitive global annual emissions data have been reported. Industrial production of polyisoprene rubber

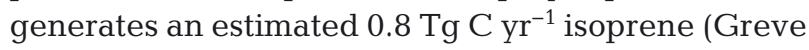
2000 ), with other processes likely producing additional emissions each year.

\section{IDENTIFICATION OF SOILS AS A SINK FOR ISOPRENE}

Given that trees are the main sources of isoprene to the atmosphere, it is perhaps not surprising that most attention has focussed on biological consumption in terrestrial environments. Landmark experiments by Cleveland \& Yavitt $(1997,1998)$ demonstrated that a variety of soils could consume isoprene down to very low levels $(<5 \mathrm{ppbv})$, indicating that microbes that could degrade isoprene were present in soil. The first reports of the isolation of bacteria that could consume isoprene were in the 1980s and 1990s (Van Ginkel et al. 1987, Ewers et al. 1990, Cleveland \& Yavitt 1998, van Hylckama Vlieg et al. 1998), and these were mainly Actinobacteria of the genera Nocardia, Arthrobacter and Rhodococcus. Related strains such as Gordonia and Mycobacterium and also proteobacterial strains were subsequently isolated from estuarine sediments (Acuña Alvarez et al. 2009, Johnston et al. 2017). Isoprene-degrading strains of Pseudomonas, Klebsiella and Alcaligenes have also been isolated from rubber-contaminated soils (Srivastva et al. 2015). More recently, the leaf environment (the phyllosphere) has yielded a number of isoprene-degraders, including further Rhodococcus strains, and a Gramnegative Variovorax strain from the leaves of the high isoprene-emitting poplar tree (Crombie et al. 2018). The leaves of willow, and soils in the vicinity of these isoprene-emitting trees, have provided isoprene-degrading strains from the genera Nocardioides, Gordonia, Rhodococcus, Ramlibacter, Variovorax and Sphingopyxis, several of which have been characterised in detail (Larke-Mejía et al. 2019, 2020, Dawson et al. 2020, Gibson et al. 2020). Isoprene degraders have also been isolated from tropical tree species (Singh et al. 2019). All of these isolates are aerobes, and thus far there has only been one report of anaerobic degradation of isoprene, describing an enrichment of homoacetogens that can use isoprene as an electron acceptor, forming a mixture of methylbutenes in the process (Kronen et al. 2019).

\section{BACTERIAL METABOLISM OF ISOPRENE}

Benchmark studies in the field of isoprene degradation by van Hylckama Vlieg et al. (1998) described the utilization of isoprene by Rhodococcus sp. AD45, isolated from freshwater sediment. In this actinobacterium, they proposed that isoprene oxidation was initiated via a soluble diiron-centre oxygenase, isoprene monooxygenase (IsoMO), and the toxic intermediate 1,2-epoxyisoprene formed was then conjugated to glutathione by a glutathione $S$-transferase (van Hylckama Vlieg et al. 1998). Rhodococcus strain AD45 subsequently became the 'workhorse' bacterium for the study of isoprene degradation. The genome sequence and expression studies of this isoprene degrader revealed 22 genes involved in isoprene metabolism, which are all located on a $300 \mathrm{kbp}$ plasmid (Fig. 2) (Crombie et al. 2015). IsoMO, consisting of a 3-subunit oxygenase, a reductase, a ferredoxin and a coupling protein, is encoded by 6 genes, 


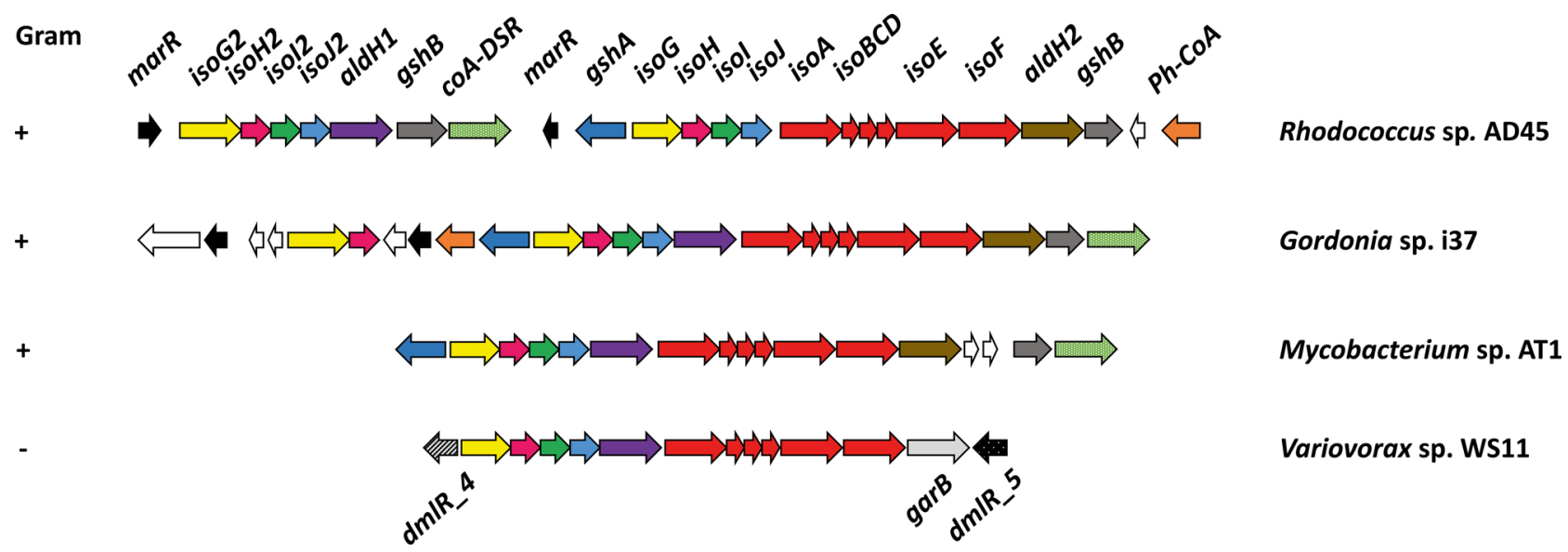

Fig. 2. Isoprene (iso) metabolic gene clusters from representative Gram-positive isoprene-degrading bacteria from aquatic ecosystems (Johnston et al. 2017) and representative Gram-negative isoprene-degrading bacterium Variovorax sp. WS11 from soils (adapted from Dawson et al. 2020). Arrows represent the direction of transcription of the iso metabolic genes. Conserved iso metabolic genes are presented in consistent colours. The sizes of the genes represent approximate scaling, where isoA from Rhodococcus sp. AD45 is $1524 \mathrm{bp}$

isoABCDEF, which are adjacent to isoGHIJ that encode enzymes involved in downstream steps in isoprene metabolism (Figs. 2 \& 3), including the glutathione $S$-transferase (IsoI). The plasmid also contains genes involved in biosynthesis of the glutathione necessary to detoxify epoxyisoprene (Crombie et al. 2015). The use of glutathione is an uncommon trait in Gram-positive bacteria (Johnson et al. 2009). Other possible intermediates include 1-hydroxy-2glutathionyl-2-methyl-3-butene (HGMB) and 2-glutathionyl-2-methyl-3-butenoate (GMBA), followed by $\beta$-oxidation to enable strain AD45 to grow on isoprene as the sole carbon and energy source (Fig. 3) (van Hylckama Vlieg et al. 2000). The isoprene metabolic pathway has previously been reviewed by Murrell et al. (2020). Loss of the $300 \mathrm{kbp}$ plasmid resulted in loss of the ability of strain AD45 to grow on isoprene. Isoprene degradation is induced by either epoxyisoprene or a subsequent intermediate product of isoprene metabolism in strain AD45, and expression studies have shown that in induced cells, iso genes are highly expressed, accounting for around $25 \%$ of all transcripts observed (Crombie et al. 2015). We are also studying putative transcriptional regulators in the vicinity of the iso gene cluster to determine how isoprene degradation is regulated.
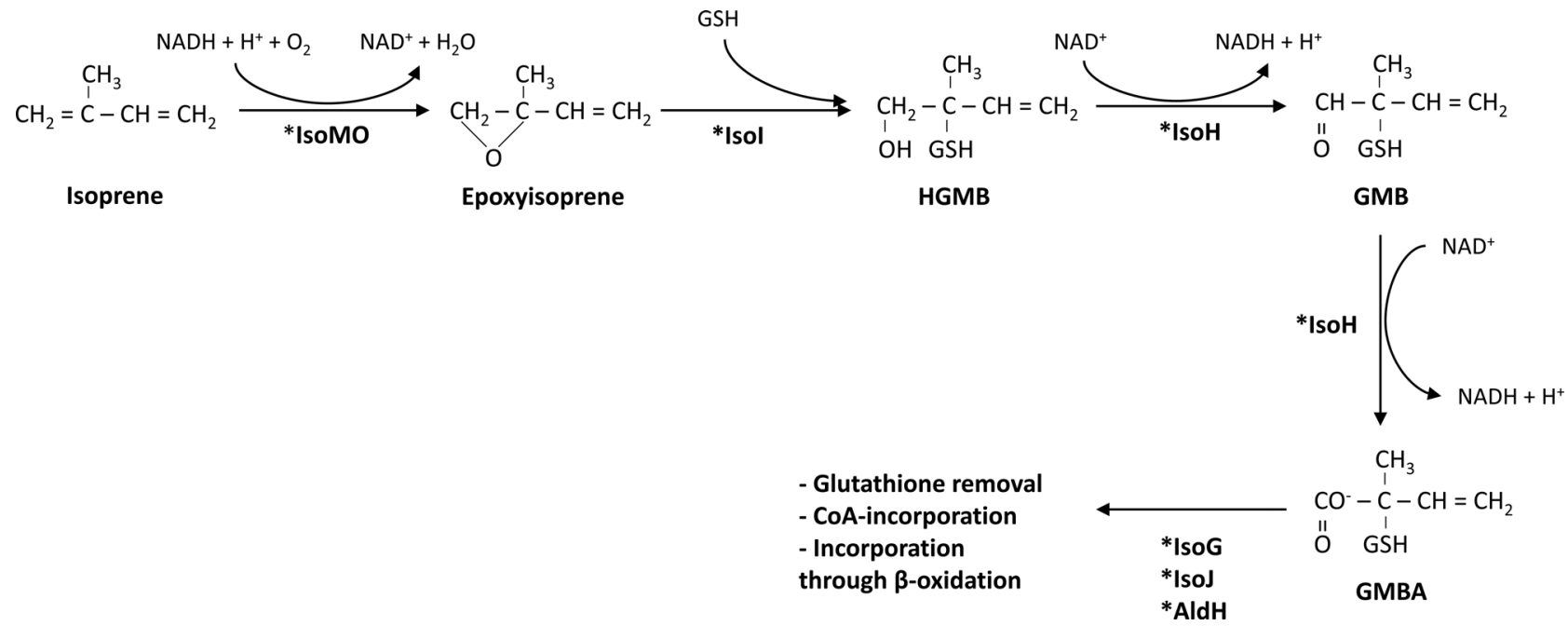

Fig. 3. Isoprene metabolic pathway, initially proposed by van Hylckama Vlieg et al. (adapted from van Hylckama Vlieg et al. 2000, Crombie et al. 2015). Asterisks: enzyme-catalysed reactions. Predicted metabolic reactions for which the enzyme/ enzymes are unknown are shown in a hyphenated list. IsoMo: isoprene monooxygenase; HGMB: 1-hydroxy-2-glutathionyl-2-methyl-3-butene; GMB:2-glutathionyl-2-methyl-3-butenal; GMBA: 2-glutathionyl-2-methyl-3-butenoic acid; 
The biochemistry of isoprene monooxygenase is also an interesting area of current study. Purification of the various components of the IsoMO and reconstitution assays reveal that all components, the dimeric oxygenase (Iso $\mathrm{A}_{2} \mathrm{~B}_{2} \mathrm{E}_{2}$ ), a Rieske-type ferredoxin (IsoC), coupling protein (IsoD) and a flavoprotein NADH reductase (IsoF), are essential for activity (Sims 2020, L. Sims et al. unpubl. data). Preliminary data also suggest that the IsoMO has a smaller substrate range than other related soluble diiron-centre monooxygenases such as the soluble methane monooxygenase (sMMO), which can co-oxidise isoprene to 1,2-epoxyisoprene (Patel et al. 1982). It will be interesting to explore the biotechnological potential of IsoMO, particularly with respect to the production of chiral epoxides from alkenes (Sims 2020).

\section{CHARACTERISATION OF OTHER ISOPRENE-DEGRADING BACTERIA}

The other well-characterised isoprene-degrader is the Gram-negative Variovorax sp. WS11, isolated from soil in the vicinity of a willow tree (Larke-Mejía et al. 2019). This isoprene-degrader also contains the iso metabolic gene cluster on a plasmid, and these genes are significantly upregulated in the presence of isoprene and epoxyisoprene (Dawson et al. 2020). Two putative LysR-type transcriptional regulators, encoded by genes located 5' and 3' of the iso metabolic gene cluster in Variovorax sp. WS11, are also the subject of further study (R. A. Dawson, A. T. Crombie \& J. C. Murrell unpubl.). The development of robust molecular genetics methods for this isoprene-degrader, such as targeted mutagenesis, is now enabling the dissection of the downstream regions of the isoprenedegradation pathway. The IsoMO of Variovorax sp. WS11 oxidises a variety of alkenes, and its activity is inhibited by several alkynes, with inhibition increasing significantly with increasing chain length (Dawson et al. 2020). Octyne was the most potent inhibitor tested, and in contrast, acetylene (at $50 \mu \mathrm{M}$ ), a strong suicide inhibitor of the related enzyme soluble methane monooxygenase, was a poor inhibitor of IsoMO. This finding paves the way for the use of specific inhibitors to determine if isoprene oxidation in environmental samples is mainly due to bona fide isoprene-degraders (most likely) or possibly due to co-oxidation reactions by the catalytically versatile sMMO present in methaneoxidising bacteria (methanotrophs), which are widely distributed in the environment.

Characterisation of other newly isolated isoprenedegraders such as Gordonia, Mycobacterium, Nocar- dioides and Sphingopyxis has increased our baseline knowledge of the metabolism of isoprene by bacteria by providing important information on the physiology, biochemistry and molecular biology of diverse genera of isoprene-degraders (Johnston et al. 2017, Larke-Mejía et al. 2019, 2020, Gibson et al. 2020). The availability of representatives across several genera has also enabled comparative genomics of isoprene-degraders, revealing that they all contain isoprene degradation gene clusters as shown in Fig. 2 (Larke-Mejía et al. 2019, Carrión et al. 2020a), which are invariably found together, either on the genome or, as in the case of Variovorax sp. WS11 and Rhodococcus strain AD45, on large plasmids (Crombie et al. 2015, Dawson et al. 2020). The ability to make glutathione also appears to be a common feature of these bacteria due to the role of glutathione in the detoxification of the reactive epoxide intermediate, 1,2-epoxyisoprene, formed by the oxidation of isoprene by IsoMO. Comparative analysis of genes encoding IsoMO has also enabled us to differentiate this key enzyme, which initiates the metabolism of isoprene by bacteria, from other soluble diironcentre monooxygenases (SDIMOs) such as sMMOs, alkene monooxygenases and toluene monooxygenases (Carrión et al. 2018).

\section{MOLECULAR ECOLOGY OF ISOPRENE-DEGRADERS}

It is now clear that iso genes fall into distinct clades when analysed phylogenetically in combination with other SDIMO-encoding genes (Leahy et al. 2003, Carrión et al. 2018). This molecular and biochemical information on isoprene-degraders has enabled the development of molecular ecology tools to determine the distribution, diversity and activity of these bacteria in the environment. Following the methodological strategies of Dumont \& Murrell (2005) and Farhan Ul Haque et al. (2019) to study the microbial ecology of aerobic methanotrophs, DNA-based detection methods have been developed to investigate isoprenedegraders in the environment (Carrión et al. 2020b). Analysis of the genomes of isoprene-degraders and alignment of iso genes has revealed a consistent organisation of isoprene degradation genes. We have used the iso $A$ gene, encoding the putative active site-containing $\alpha$-subunit of the oxygenase component of IsoMO, as a phylogenetic marker to determine the presence of isoprene-degraders in DNA extracted from a number of different (mostly terrestrial) environments, including various soils, sedi- 
ments, and leaf samples. isoA-specific PCR primer sets were designed which do not 'cross-react' with the corresponding homologues encoding the $\alpha$-subunits of other SDIMOs, for example the large subunit of sMMO (mmoX) (El Khawand et al. 2016, Carrión et al. 2018). These isoA PCR primer sets have provided valuable data on the distribution and diversity of isoprene-degraders in various environments, and iso $A$ sequences have complemented data on iso $A$ from cultivated isoprene-degraders to assist in mapping the phylogeny of these IsoMO enzymes (Crombie et al. 2018, Carrión et al. 2020a, Dawson et al. 2020, Murrell et al. 2020). For example, screening of soil and leaf samples not only revealed the presence of actinobacterial isoprene-degraders such as Rhodococcus, Gordonia, Mycobacterium and Nocardioides and proteobacterial representatives Sphingopyxis and Variovorax, but also the presence of sequences representing uncultivated isoprene-degraders (Carrión et al. 2020a). A quantitative PCR assay based on iso $A$ has also been developed which, when normalised against 16S rRNA gene copies in DNA from environmental samples, revealed the relative abundance of putative isoprene-degraders. For example, iso $\mathrm{A}$ copies appeared to be most abundant in soil collected from within the vicinity of high isoprene-emitting trees such as oil palm, poplar and willow with between $\sim 75$ and 300 copies of isoA genes per million 16S rRNA genes (Carrión et al. 2018, 2020a). Surveys such as these now need to be carried out in other environments (see Section 11).

Amplification of isoA sequences by PCR reveals the presence of isoprene-degraders in an environmental sample but this approach does not necessarily retrieve the most active isoprene-oxidisers and, hence, as with methanotrophs, DNA-stable isotope probing (DNA-SIP) (Dumont \& Murrell 2005, Kröber \& Eyice 2019) was used to identify the most active isoprene-degraders in a variety of soil, leaf and estuarine sediment samples. Early DNA-SIP experiments with ${ }^{13} \mathrm{C}$-labelled isoprene used sediment from the Colne Estuary, UK, originally investigated for isoprene-degradation potential by Acuña Alvarez et al. (2009). This led to the identification of actinobacterial isoprene-degraders such as Gordonia, Mycobacterium and Rhodococcus (Johnston et al. 2017). Soil from the vicinity of willow trees also revealed the presence of similar Actinobacteria, but also of Betaproteobacteria, such as Comamonas and Variovorax, which are capable of consuming isoprene (El Khawand et al. 2016, Larke-Mejía et al. 2019). El Khawand et al. (2016) showed that the iso $A$ sequences from marine and estuarine iso- prene-degrading bacteria cluster together in a phylogenetic tree (as in Fig. 4), while the iso $A$ sequences from isoprene-degraders isolated from terrestrial and freshwater samples lacked a clear environment-phylotype relationship. Cultivationindependent studies, which combined functional gene probing with DNA-SIP, provided further isoA sequences to use alongside iso $A$ sequences from cultivated representatives, thus improving considerably the robustness of isoA phylogenetic trees and enabling the detection of uncultivated isoprenedegraders in the environment (Carrión et al. 2018). By combining DNA-SIP with metagenomics, using a 'focussed metagenomics' strategy, the near-complete genomes of key, active isoprene-degrading bacteria have been retrieved from several environments (Carrión et al. 2018, 2020a, Crombie et al. 2018, Larke-Mejía et al. 2019). Study of these genomes has yielded not just individual iso genes but also complete iso metabolic gene clusters containing isoABCDEF and isoGHIJ (Fig. 2), providing valuable data for comparative genomics, aiding phylogenetic analysis and revealing the presence of new isoprene-degraders without the need for cultivation. For example, leaf washings of the high isoprene-emitter white poplar Populus alba were incubated in microcosms with ${ }^{13} \mathrm{C}$-labelled isoprene. After assimilation of labelled isoprene, heavy DNA from active isoprene-degraders in these environmental samples was isolated by $\mathrm{CsCl}$ density-gradient centrifugation and sequenced. Near-complete genomes of putative isoprene-degrading Rhodococcus and Variovorax were obtained (Crombie et al. 2018). The power of this focussed metagenomics approach was demonstrated by cloning the iso genes from the Variovorax genome into a mutant Rhodococcus strain AD45 that had been cured of the $300 \mathrm{kbp}$ plasmid containing all of its iso genes (also a convenient expression system for future sitedirected mutagenesis studies on IsoMO), which therefore did not oxidise isoprene. The isoABCDEF gene cluster from the Variovorax genome conferred on this Rhodococcus mutant the ability to oxidise isoprene, thus proving that the iso genes retrieved through DNA-SIP-enabled metagenomics were indeed from a bona fide isoprene-degrader (Crombie et al. 2018). Informed by these molecular data, enrichment and isolation strategies were used to isolate representative isoprene-degraders of the genus Variovorax, including Variovorax sp. WS11 described earlier, which has now become the Gramnegative model isoprene-degrader of choice (along with the actinobacterial Rhodococcus strain AD45) 


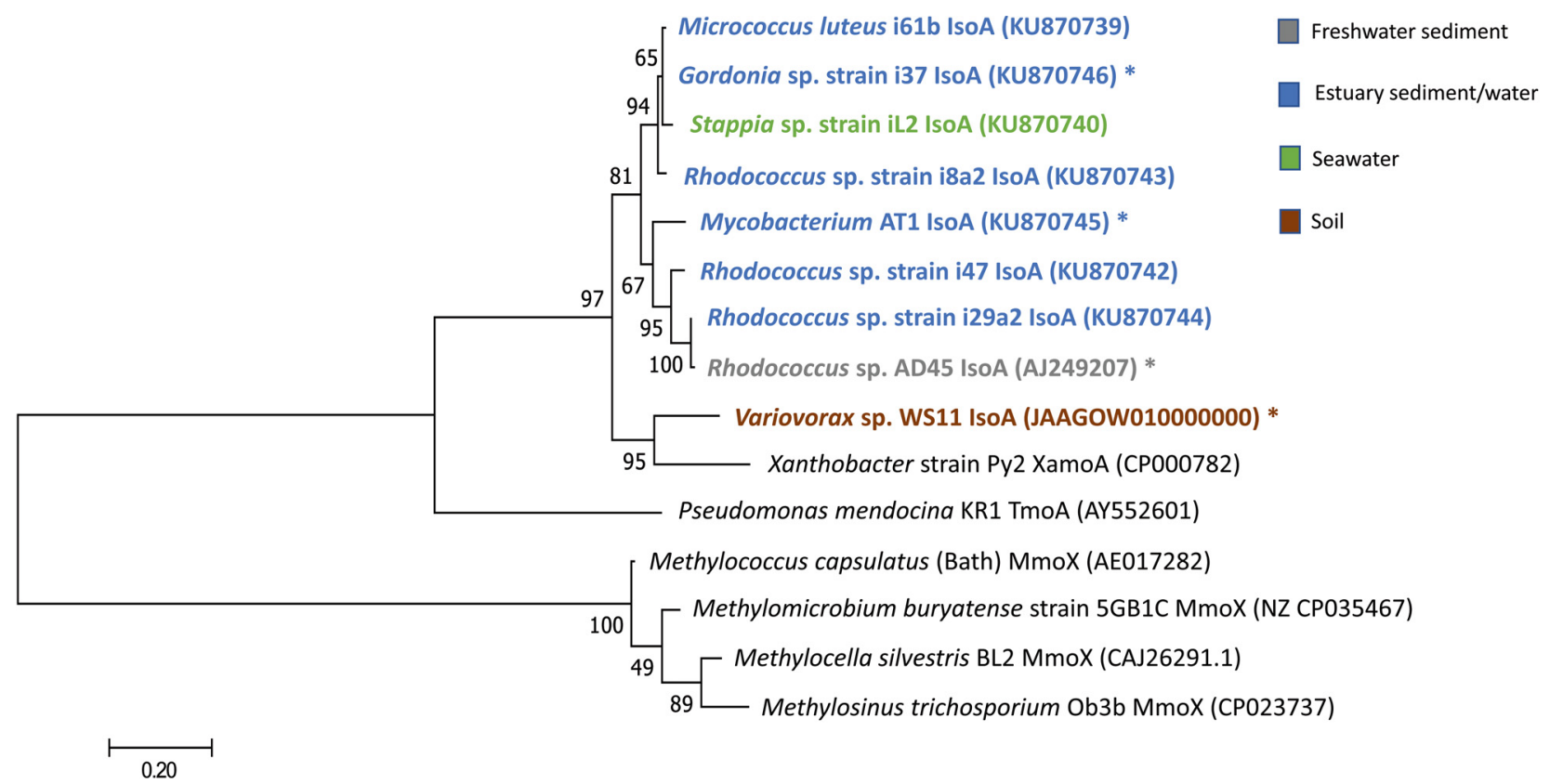

Fig. 4. Phylogeny based on ratified IsoA amino acid sequences (colour-coded) from aquatic isoprene-degraders and from the soil-derived isoprene-degrader Variovorax sp. WS11. *: genome-sequenced isoprene-degrading bacterium which contains a verified iso metabolic gene cluster. Included for reference: SDIMO $\alpha$-oxygenase subunits from the soluble methane monooxygenase (MmoX) and toluene 4-monooxygenase (TmoA). The closest relative to IsoA, the $\alpha$-oxygenase subunit from the alkene monooxygenase of Xanthobacter sp. PY2 (XamoA) was also included for reference. This tree was drawn using the maximum likelihood programme in Mega7 (Kumar et al. 2016), with bootstrap values (500 replications) shown at the nodes. Branch lengths measured in the number of substitutions per site

to study the metabolism and pathways of isoprene degradation in bacteria (Dawson et al. 2020).

We now have a good understanding of the types of isoprene-degraders present in the terrestrial environment and also of the biology of isoprene degradation, with the majority of isolates from soils, leaves and sediments. Here, we review the state of knowledge on isoprene in marine and freshwater environments and highlight the potential for future research on this topic.

\section{EMISSION OF ISOPRENE BY TERRESTRIAL WETLANDS}

Wetlands are an interesting but understudied environment when considering the cycling of biogenic volatile organic compounds (BVOCs). Temperaturedependent shifts in volatile organic compound (VOC) emissions from terrestrial plants are well-established (Lantz et al. 2019), but wetlands may respond differently than drier ecosystems due to buffering of extremes by the high specific heat capacity of water and the cooling effects of flowing and evaporating water. Few measurements of isoprene emissions from fenland plants are available (Seco et al. 2020), and the isoprene-degrading communities of these ecosystems are currently unstudied. Several studies have identified the isoprene-emitting potential of moss species in arctic and sub-arctic wetlands (Janson \& De Serves 1998, Ekberg et al. 2009, 2011, Lindwall et al. 2016, Hellén et al. 2020, Seco et al. 2020). Swedish Sphagnum and graminoid-rich fens emit isoprene at $219.8 \pm 125.8$ and $93 \pm 22 \mu \mathrm{mol} \mathrm{m}^{-2} \mathrm{~d}^{-1}$, respectively, exhibiting diurnal regulation due to light and temperature (Janson \& De Serves 1998, Seco et al. 2020). In contrast to leaves, which heat and cool rapidly due to a large surface area in direct contact with the air, bodies of water react much more slowly. This difference may contribute to the observation that the temperature history of the previous $48 \mathrm{~h}$ is a significant influencer of wetland isoprene emission (Ekberg et al. 2009, 2011). Moisture content was also a potent controller of isoprene emission, with plants from dry and wet fenland sites producing 70 and $2000 \mu \mathrm{g} \mathrm{C} \mathrm{m}^{-2} \mathrm{~h}^{-1}$, respectively (Janson \& De Serves 1998), with Sphagnum balticum producing $30 \%$ more isoprene under moist conditions compared to dry conditions (Ekberg et al. 2011). More direct comparisons of isoprene emission from plants in dry and wetland sites are required to adequately define the relative contributions of each to the iso- 
prene budget. Algae may also be key contributors to isoprene emissions from wetlands, but their role will be discussed in Section 10. Although global isoprene emission from wetlands is difficult to quantify, due to insufficient measurements and because estimates of global wetland coverage range from 0.54-21.26 million $\mathrm{km}^{2}$ (Hu et al. 2017), the contribution of wetlands to the global isoprene budget is low compared to dryland terrestrial plants in warm climates, with oil palm plantations alone producing an estimated $7800 \mu \mathrm{g} \mathrm{C}$ $\mathrm{m}^{-2} \mathrm{~h}^{-1}$ (Misztal et al. 2011). The inclusion of isoprene flux measurements in future studies, as well as studies of the isoprene-degrading communities that colonise isoprene-emitting mosses and wider wetland ecosystems, would greatly improve our understanding of the contribution of these ecosystems to isoprene cycling.

\section{EMISSION OF ISOPRENE BY FRESHWATER SOURCES}

While lakes and other fresh waters are significant sources of VOCs such as methane (Wik et al. 2016), the contribution of freshwater ecosystems to isoprene emissions is still a point of much debate. Isopreneproducing species of phytoplankton (both marine and freshwater) have been reported from diverse taxa (Exton et al. 2013, Steinke et al. 2018), with isoprene emission potentially linked to stress responses, as in plants (Zuo et al. 2012a,b, Meskhidze et al. 2015, Dani \& Loreto 2017, Xu et al. 2017). The evolutionary basis for isoprenoid biosynthesis by algae is complicated; while plants use a combination of the cytosolic mevalonate (MVA) pathway and the plastid-localised methylerythritol 4-phosphate (MEP) pathway (Zhao et al. 2013), most green algae only use the MEP pathway, and some red algae and charophyte green algae use the MVA pathway (Lohr et al. 2012, Bentlage et al. 2016). Steinke et al. (2018) reported the flux of both isoprene and dimethyl sulfide (DMS) from the oligotrophic Lake Constance, Central Europe. Of 10 phytoplankton strains isolated from this lake, 5 emitted isoprene, at rates between 12.6 and $174.3 \mathrm{nmol}$ $(\mathrm{g} \mathrm{chl} \mathrm{a})^{-1} \mathrm{~h}^{-1}$, lower than the overall estimated lake flux of $304 \mathrm{nmol}(\mathrm{g} \mathrm{chl} a)^{-1} \mathrm{~h}^{-1}$. This discrepancy was attributed to their screening technique which may have excluded some isoprene-emitting taxa, or due to the variability of isoprene emission with changing environmental conditions. In another study, it was shown that the Villasjön Lake (northern Sweden) emitted $20 \pm 10 \mu \mathrm{mol} \mathrm{m}{ }^{-2} \mathrm{~d}^{-1}$ in the summer (Seco et al. 2020). Isoprene emission by lakes was suggested to rival terrestrial plants in areas with high lake coverage and low plant coverage, although this is yet to be explored (Steinke et al. 2018).

\section{ISOPRENE EMISSIONS BY COASTAL AND OPEN MARINE ENVIRONMENTS}

Little information is available with regards to the emission of isoprene from estuarine environments. According to a simple model which calculated the annual rate of isoprene production for the Colne Estuary, UK, using data from benthic incubations, intertidal sediments from the Colne Estuary were responsible for an estimated $681 \mu \mathrm{mol} \mathrm{m}{ }^{-2} \mathrm{yr}^{-1}$ (Exton et al. 2012). Comparisons with other freshwater and marine sources of isoprene are difficult to conduct due to the scarcity of flux measurements. Long-term studies of isoprene flux are required from a variety of aquatic environments in order to fully quantify the relative contributions of each type of ecosystem to annual isoprene emissions. Sediment samples from the Colne Estuary emitted an average of $8.38 \pm$ $1.18 \mathrm{nmol}$ isoprene $\mathrm{m}^{-2} \mathrm{~h}^{-1}$, with little variation between the head and mouth of the estuary (Exton et al. 2012). The dissolved concentration of isoprene in the estuary was higher at low tide which, coupled with the high isoprene production from sediments, led to the conclusion that the microphytobenthos was primarily responsible for the emission of isoprene (Exton et al. 2012).

Estimates of annual marine emissions of isoprene range from 0.1 to $11.6 \mathrm{Tg} \mathrm{C} \mathrm{yr}^{-1}$ (Broadgate et al. 1997, Luo \& Yu 2010, Shaw et al. 2010, Conte et al. 2020). The disparity between estimates is a result of the differing measurement or estimation techniques used and of the effects of seasonality and corresponding productivity of the measurement period in question. Bottom-up estimates couple laboratory-based measurements of isoprene emission by phytoplankton with satellite-based measurements of phytoplankton biomass, based on the abundance of chlorophyll a (Broadgate et al. 1997, Shaw et al. 2003, Luo \& Yu 2010, Halsey et al. 2017, Davie-Martin et al. 2020, Li et al. 2020). Top-down approaches combine measurements of isoprene flux from seas with inversion modelling and global scaling (Arnold et al. 2009, Luo \& Yu 2010, Shaw et al. 2010). Luo \& Yu (2010) calculated annual aquatic isoprene emission rates of 0.32 and 11.6 $\mathrm{Tg} \mathrm{C} \mathrm{yr}^{-1}$ by bottom-up and top-down approaches, respectively, demonstrating the need for improvements in our understanding of the factors constraining estimates of isoprene emission. 
Various studies have reported in situ measurements of isoprene from seawater (Milne et al. 1995, Broadgate et al. 1997, Tran et al. 2013, Kameyama et al. 2014, Ooki et al. 2015), often relying on purgeand-trap or cryogenic enrichment systems (Table 1). Measurements of isoprene concentrations in seawater range from $<1$ to $541 \mathrm{pmol}^{-1}$, with the highest concentrations typically reported in productive coastal zones or regions of phytoplankton blooms (Milne et al. 1995, Exton et al. 2012, Tran et al. 2013, Kameyama et al. 2014, Zindler et al. 2014, Ooki et al. 2015, Booge et al. 2016). The requirement for large samples and interference by other BVOCs may result in overestimations of isoprene concentrations, prompting Hrebien et al. (2020) to develop the cumulative headspace injection technique. The limit of detection of this technique was suitable for use in productive tropical coastal regions. Also, Li et al. (2020) reported a novel technique which relied on adsorption and desorption at room temperature, with measurements comparable to those of previous studies.

Direct measurements of marine isoprene concentrations and fluxes have been gathered from only a small number of areas, with little spatiotemporal coverage (Table 1) (Hackenberg et al. 2017, Conte et al. 2020, Li et al. 2020). While this relative lack of data precludes large-scale modelling of marine isoprene cycling, it has aided our understanding of various biotic and abiotic drivers of isoprene emission. As in plants, isoprene emission may play a role in the resistance of algae to abiotic stresses (Zuo et al. 2012a,b, Meskhidze et al. 2015, Xu et al. 2017). Isoprene is synthesised within the plastid (Bentlage et al. 2016, Zuo 2019) in a manner which is strongly influenced by temperature and photosynthetically active radiation (PAR) (Broadgate et al. 2004, Halsey et al. 2017, Booge et al. 2018, Conte et al. 2020, Davie-Martin et al. 2020). This relationship is due to the influence of these factors on phytoplankton growth, and also the requirement of photosynthetic electron transport for the production of isoprenoid precursors (Broadgate et al. 1997, Rasulov et al. 2009, Niinemets \& Sun 2015, Conte et al. 2020, Tripathi et al. 2020). Phytoplankton blooms are a seasonal driver of increasing isoprene concentrations, meaning that drivers of phytoplankton growth must be taken into account when considering the annual flux of isoprene (Kameyama et al. 2014, Ooki et al. 2019, Davie-Martin et al. 2020, Rodríguez-Ros et al. 2020, Tripathi et al. 2020). Ooki et al. (2015) identified a maximum in isoprene concentration between 10 and $20^{\circ} \mathrm{C}$, consistent with phytoplankton blooming temperatures. Measurements of isoprene have typically identified a diel cycle of increasing isoprene concentration with increasing light and temperature (Matsunaga et al. 2002, Broadgate et al. 2004, Liakakou et al. 2007, Acuña Alvarez et al. 2009, Shaw et al. 2010, Exton et al. 2012). Exton et al. (2012) reported peaks of isoprene concentration in the Colne Estuary in the daytime and night-time, although the night-time peak was significantly smaller and influenced by the aforementioned tidal changes and proximity to the sediment. A diel pattern of isoprene concentration/emission was also demonstrated in Lake Constance (Steinke et al. 2018). Daytime and night-time peaks were also identified in the western North Pacific, with a larger peak in the daytime (Matsunaga et al. 2002). However, the concentration of isoprene in the air was greater at night (Matsunaga et al. 2002). Similar observations were made in the Yellow Sea/East China Sea as isoprene concentrations peaked at midday but were still detected at night at a lower concentration (Wu et al. 2021). The highest marine and freshwater concentrations of isoprene were reported in the afternoon rather than morning, with seasonal studies reporting higher concentrations in summer than at other times of year (Broadgate et al. 1997, Seco et al. 2020). Contrary to these observations, Bonsang et al. (1992) and Hackenberg et al. (2017) identified no significant diel variation in isoprene concentration, although the latter study suggested that the lack of diel variation may have been due to sampling in remote regions with little biological activity. However, a consistent correlation between surface isoprene concentrations and the sum of photoprotective carotenoids was found, providing an alternative metric to chlorophyll a content (Hackenberg et al. 2017). Oligotrophic zones, which are often limited in nutrients such as iron, have reported lower concentrations of isoprene than more productive areas closer to coastlines (Hackenberg et al. 2017, Rodríguez-Ros et al. 2020), while Davie-Martin et al. (2020) reported that net production of isoprene was higher in the open ocean in the eastern parts of the North Atlantic Ocean and decreased with proximity to the coastal shelf in March in the northern Atlantic.

The sea-surface microlayer (SML) concentrates organic matter on the ocean's surface, where photochemical reactions produce organic vapours, including isoprene. Initial estimates of the photochemical production of isoprene ranged from 14.4 to $33120 \mathrm{nmol} \mathrm{m} \mathrm{d}^{-1}$ (Ciuraru et al. 2015). Brüggemann et al. (2018) updated these predictions using parameters such as biological net productivity and 
Table 1. Reported concentrations of isoprene and flux measurements according to sampling location and type. Values in brackets were derived from models. NA: not available; GBR: Great Barrier Reef

\begin{tabular}{|c|c|c|c|c|}
\hline Sampling area & $\begin{array}{l}\text { Isoprene flux } \\
\left(\text { nmol m}{ }^{-2} d^{-1}\right)\end{array}$ & $\begin{array}{l}\text { Isoprene conc. } \\
\left(\mathrm{pmol} \mathrm{l}^{-1}\right)\end{array}$ & Sample type & Reference \\
\hline \multicolumn{5}{|l|}{ Marine } \\
\hline \multirow[t]{4}{*}{ Southern Ocean } & $181-313.1$ & $0.2-395$ & In situ, seawater, & Meskhidze \& Nenes $(2007)^{a}$, \\
\hline & $(28.8-1238.4)$ & $(3-13)$ & shipboard measurement & Kameyama et al. (2014) \\
\hline & NA & $1-94$ & Seawater, purge trap system & Rodríguez-Ros et al. (2020) \\
\hline & 14.5 & 5.6 & $\begin{array}{c}\text { In situ, seawater, } \\
\text { shipboard measurement }\end{array}$ & Ooki et al. (2015) \\
\hline \multirow[t]{2}{*}{ Arctic Ocean } & $22-46$ & $1-541$ & In situ, seawater, & Tran et al. (2013) \\
\hline & 23.8 & 9.5 & $\begin{array}{l}\text { shipboard measurement } \\
\text { In situ, seawater, } \\
\text { shipboard measurement }\end{array}$ & Ooki et al. (2015) \\
\hline $\begin{array}{l}\text { Southern Atlantic } \\
\text { Ocean }\end{array}$ & NA & $4.8-57.1$ & $\begin{array}{l}\text { Seawater, purge-and-trap } \\
\text { system }\end{array}$ & Rodríguez-Ros et al. (2020) \\
\hline $\begin{array}{l}\text { Eastern Atlantic } \\
\text { Ocean }\end{array}$ & $\begin{array}{c}48-96 \\
(36-216)\end{array}$ & $13.7-60.8$ & $\begin{array}{l}\text { Seawater, laboratory } \\
\text { measurement }\end{array}$ & $\begin{array}{l}\text { Baker et al. (2000), } \\
\text { Arnold et al. (2009) }\end{array}$ \\
\hline Florida Straits & $\begin{array}{l}9.51-101.2 \\
(5.8-244.8)\end{array}$ & $9.8-50.8$ & $\begin{array}{c}\text { In situ, seawater and } \\
\text { atmospheric measurements }\end{array}$ & $\begin{array}{l}\text { Milne et al. (1995), } \\
\text { Arnold et al. (2009) }\end{array}$ \\
\hline $\begin{array}{l}\text { North Pacific/ } \\
\text { Mediterranean Sea }\end{array}$ & 158.4 & $6.7-25$ & $\begin{array}{c}\text { Seawater, laboratory } \\
\text { measurement }\end{array}$ & Bonsang et al. (1992) \\
\hline North Pacific & NA & 42.6 & $\begin{array}{l}\text { In situ, room temperature- } \\
\text { enriched thermal desorption }\end{array}$ & Li et al. (2020) \\
\hline Northeast Pacific & $10.1-28.3$ & $2-12$ & Seawater, purge-and-trap system & Moore \& Wang (2006) \\
\hline \multirow[t]{3}{*}{ Northwest Pacific } & $\begin{array}{c}32-300 \\
(14.4-158.4)\end{array}$ & $12-94$ & Marine air and seawater & $\begin{array}{l}\text { Matsunaga et al. (2002), } \\
\text { Arnold et al. (2009) }\end{array}$ \\
\hline & $1.3-20.2$ & NA & $\begin{array}{l}\text { MODIS chlorophyll observations } \\
\text { coupled with phytoplankton study }\end{array}$ & Palmer \& Shaw (2005) \\
\hline & $21.4-143.8$ & $12.4-114.1$ & $\begin{array}{l}\text { In situ, seawater, } \\
\text { shipboard measurement (1986) }\end{array}$ & Ooki et al. (2015) \\
\hline North Sea & $1.4-67.7$ & $0.7-54.3$ & $\begin{array}{l}\text { Seawater, in situ, cryo-trap system. } \\
\text { Estimation by Liss and Merlivat } \\
\text { relationship }\end{array}$ & $\begin{array}{l}\text { Liss \& Merlivat (1986), } \\
\text { Broadgate et al. (1997) }\end{array}$ \\
\hline $\begin{array}{l}\text { Yellow Sea/ } \\
\text { East China Sea }\end{array}$ & 52.4 & 17.1 & $\begin{array}{l}\text { Seawater and atmospheric } \\
\text { samples. Laboratory analysis }\end{array}$ & Wu et al. (2021) \\
\hline $\begin{array}{l}\text { Coastal Japan } \\
\text { (Hokkaido) }\end{array}$ & NA & 27.54 & $\begin{array}{l}\text { In situ, room temperature- } \\
\text { enriched thermal desorption }\end{array}$ & Li et al. (2020) \\
\hline Indian Ocean & $7.3-232.3$ & $6.5-51.9$ & $\begin{array}{c}\text { In situ, seawater, } \\
\text { shipboard measurement }\end{array}$ & Ooki et al. (2015) \\
\hline \multicolumn{5}{|l|}{ Estuary } \\
\hline Colne Estuary, UK & $201.1 \pm 28.3$ & $0.7-451.8$ & $\begin{array}{c}\text { Estuary water, cryo-trap } \\
\text { system. Sediment sampling }\end{array}$ & Exton et al. (2012) \\
\hline \multicolumn{5}{|l|}{ Intertidal rock pool } \\
\hline Mace Head, Ireland & 974.9 & $24.9-865.5$ & $\begin{array}{c}\text { Seawater and seaweed, } \\
\text { cryo-trap system. In situ rock pool } \\
\text { study with stainless steel bucket }\end{array}$ & Broadgate et al. (2004) \\
\hline \multicolumn{5}{|l|}{ Reef sediments } \\
\hline Heron Island (GBR) & $194.4-290.4$ & NA & Sediment, benthic chambers & Hrebien et al. (2020) \\
\hline Lizard Island (GBR) & $69.6-139.2$ & NA & Sediment, benthic chambers & Hrebien et al. (2020) \\
\hline \multicolumn{5}{|l|}{ Lake } \\
\hline Lake Constance & 350.4 & $183-722$ & Lake water, purge-and-trap system & Steinke et al. (2018) \\
\hline Lake Villasjön & $600-20000$ & NA & Eddy covariance measurements & Seco et al. (2020) \\
\hline \multicolumn{5}{|l|}{ Fenland } \\
\hline $\begin{array}{l}\text { Northern Sweden, } \\
\text { Graminoid }\end{array}$ & $300-93000$ & NA & Eddy covariance measurements & Seco et al. (2020) \\
\hline
\end{tabular}


mean surface wind speeds, estimating $0.7-1.52 \mathrm{Tg} \mathrm{C}$ $\mathrm{yr}^{-1}$ isoprene from the SML. More recently, a global simulation of isoprene emission estimated $0.39 \mathrm{Tg} \mathrm{C}$ $\mathrm{yr}^{-1}$ due to photoproduction in the SML (Conte et al. 2020). Photochemical production of isoprene from the SML may account for a portion of the deviation between top-down and bottom-up estimates of aquatic isoprene emissions. The fact that these emissions are dependent on sunlight may also contribute to the observations of a diel pattern of isoprene emissions. The concentration of isoprene in the SML remained enriched at low windspeeds, requiring approximately $10 \mathrm{~m} \mathrm{~s}^{-1}$ before the depletion of isoprene was observed (Ciuraru et al. 2015); this correlated with the observations of marine particle nucleation made by Wen et al. (2006), as they also found that greater wind speed increased the likelihood of nucleation occurrence. Enrichments of SML isoprene may also influence local communities of isoprene-degrading bacteria, providing a rich area for molecular ecology studies.

Isoprene emissions associated with phytoplankton blooms and other isoprene-emitting species may result in changes in cloud formation and local climate due to the influence of isoprene on secondary organic aerosol (SOA) formation (Meskhidze \& Nenes 2007, Cropp et al. 2018). However, Arnold et al. (2009) estimated that isoprene-derived SOA could only account for $0.5 \%$ of marine organic carbon aerosols, while $\mathrm{Hu}$ et al. (2013) posited that phytoplankton blooms could produce sudden spikes in SOA over remote oceans. Alternatively, isoprene may be an insignificant contributor to global marine SOA yield but a significant contributor to SOA yield over tropical oceans (Gantt et al. 2009), and SOA formation has been correlated with both seasonal variation and chlorophyll a (Cui et al. 2019). The important impact of isoprene on global SOA formation over aquatic ecosystems cannot be accurately estimated at present due to the incomplete understanding of aquatic isoprene emissions. Two examples illustrate the uncertainties associated with isoprene in the marine environment. A recent study estimated that as much as $4.8 \mathrm{Tg} \mathrm{C} \mathrm{yr}^{-1}$ of isoprene was emitted solely by diatoms in temperate oceans (Dani et al. 2017), nearly half of the high end of previous total marine estimates (Luo \& Yu 2010), and some diatom species produce isoprene at rates as high as $35 \mu \mathrm{g}(\mathrm{g} \mathrm{chl} \mathrm{a})^{-1} \mathrm{~h}^{-1}$ (Meskhidze et al. 2015). Isoprene concentrations in a hypersaline saltern (Mallorca) ranged from 209 to 313 pmol $\mathrm{l}^{-1}$, corresponding with salinity ranging from 4 to $23 \%$, respectively (Rinnan et al. 2014). Although the primary isoprene emitters in this environment were not identified, the phototrophic communities tend to be composed of benthic cyanobacteria and chlorophytes, such as Dunaliella salina (Rinnan et al. 2014). Further studies are required to investigate the biological components of isoprene cycling in extreme environments, particularly hypersaline environments which constitute a considerable proportion of the Earth's surface.

\section{ISOPRENE EMISSION BY MICROALGAE, MACROALGAE AND CORAL-ASSOCIATED SPECIES}

Most reports of aquatic isoprene-emitting organisms focus on phytoplankton (Table 2), with only one study demonstrating isoprene emission by macroalgae

Table 2. Published rates of isoprene emission in different aquatic isoprene-emitting organisms, collated by Booge et al. (2016)

\begin{tabular}{|c|c|c|}
\hline $\begin{array}{l}\text { Taxonomic } \\
\text { group }\end{array}$ & $\begin{array}{l}\text { Isoprene emission range } \\
\left(\mu \mathrm{mol}(\mathrm{g} \mathrm{chl} a)^{-1} \mathrm{~d}^{-1}\right)\end{array}$ & Reference \\
\hline Haptophytes & $\begin{array}{c}1.24-2.73 \\
2.88-15.36 \\
5.4-11.45\end{array}$ & $\begin{array}{l}\text { Arnold et al. (2009) } \\
\text { Exton et al. (2013) } \\
\text { Colomb et al. (2008) }\end{array}$ \\
\hline Cyanobacteria & $\begin{array}{c}2.40-22.10 \\
2.40-11.76 \\
1.4-1.5 \\
0.02 \pm 0.003-0.16 \pm 0.04^{b}\end{array}$ & $\begin{array}{l}\text { Arnold et al. (2009) } \\
\text { Exton et al. (2013) } \\
\text { Shaw et al. (2003) } \\
\text { Steinke et al. (2018) }\end{array}$ \\
\hline Chlorophytes & $\begin{array}{c}2.85 \\
1.2 \\
0.36 \pm 0.22 \\
83.28^{\mathrm{a}} \\
0.16 \pm 0.02^{\mathrm{b}} \\
0.049 \pm 0.036^{\mathrm{b}}\end{array}$ & $\begin{array}{l}\text { Colomb et al. (2008) } \\
\text { Exton et al. (2013) } \\
\text { Bonsang et al. (2010) } \\
\text { Broadgate et al. (2004) } \\
\text { Halsey et al. (2017) } \\
\text { Steinke et al. (2018) }\end{array}$ \\
\hline Diatoms & $\begin{array}{c}0.00-10.10 \\
0.72-9.36 \\
28.48 \\
0.56-1.32 \\
0.36 \pm 0.17-12.38 \pm 5.81^{\mathrm{c}} \\
0.47 \pm 0.07^{\mathrm{b}}\end{array}$ & $\begin{array}{l}\text { Arnold et al. (2009) } \\
\text { Exton et al. (2013) } \\
\text { Colomb et al. (2008) } \\
\text { Bonsang et al. (2010) } \\
\text { Dani et al. (2017) } \\
\text { Halsey et al. (2017) }\end{array}$ \\
\hline Dinoflagellates & & \\
\hline Cryptophytes & $\begin{array}{c}9.36 \pm 0.72 \\
0.01 \pm 0.009^{b}\end{array}$ & $\begin{array}{l}\text { Exton et al. (2013) } \\
\text { Steinke et al. (2018) }\end{array}$ \\
\hline \multicolumn{3}{|c|}{ 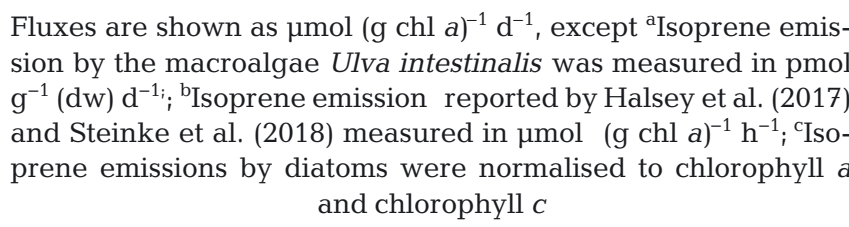 } \\
\hline
\end{tabular}


Table 3. Emission of isoprene by macroalgae and corals. dw: dry weight; fw: fresh weight

\begin{tabular}{|lcccc|}
\hline $\begin{array}{l}\text { Major taxo- } \\
\text { nomic group }\end{array}$ & $\begin{array}{c}\text { Specific } \\
\text { group }\end{array}$ & $\begin{array}{c}\text { Isoprene } \\
\text { emission rate }\end{array}$ & Units & Reference \\
\hline Macroalgae & Red algae & $0.31-5.26$ & $\mathrm{pmol} \mathrm{g}^{-1}(\mathrm{dw}) \mathrm{h}^{-1}$ & $\begin{array}{c}\text { Broadgate et al. } \\
(2004)\end{array}$ \\
& Brown algae & $0.69-1.38$ & $\mathrm{pmol} \mathrm{g}^{-1}(\mathrm{dw}) \mathrm{h}^{-1}$ & $\begin{array}{c}\text { Broadgate et al. } \\
(2004)\end{array}$ \\
Corals & $\begin{array}{c}\text { Acropora } \\
\text { aspera } \\
\text { Acropora } \\
\text { horrida }\end{array}$ & $0.01-0.058$ & $\mathrm{ng} \mathrm{g}^{-1}(\mathrm{fw}) \mathrm{h}^{-1}$ & $\begin{array}{c}\text { Swan et al. } \\
(2016) \\
\text { This study }\end{array}$ \\
& $0.97-2.24$ & $\mathrm{pmol} \mathrm{cm}^{-1} \mathrm{~h}^{-1}$ & \\
\hline
\end{tabular}

(Table 3) (Broadgate et al. 2004). All 10 species of seaweed tested, including the abundant macroalga Ulva intestinalis, emitted isoprene in a temperature- and light-dependent manner. The red alga Asparagopsis armata was the highest producer, while the brown alga Ascophyllum nodosum was the lowest producer, with isoprene emission rates of 5.26 and $0.46 \mathrm{pmol}$ $\mathrm{g}^{-1}$ (dry weight, $\mathrm{dw}$ ) $\mathrm{h}^{-1}$, respectively (Broadgate et al. 2004). Aquatic isoprene emitters may continue to produce isoprene in the dark, albeit at a lower rate than the photosynthesis-driven isoprene emission rate (Shaw et al. 2003, Ooki et al. 2019). Studies in terrestrial plants have demonstrated the sudden cessation of isoprene emission in the absence of light, with only a brief spike in emission concurrent with the release of the stored isoprenoid precursor DMAPP (Rasulov et al. 2009, Li \& Sharkey 2013, Weise et al. 2013). The estimated rate of isoprene production in macroalgae only decreased from $30 \mathrm{pmol} \mathrm{g}^{-1}(\mathrm{dw}) \mathrm{h}^{-1}$ during the day to $10 \mathrm{pmol} \mathrm{g}^{-1}$ (dw) $\mathrm{h}^{-1}$ at night. Likewise, cyanobacteria and diatoms retained approximately $10 \%$ of their daytime rate of isoprene emission when in dark conditions (Shaw et al. 2003, Ooki et al. 2019). Exton et al. (2012) demonstrated a peak in isoprene emission at night in the Colne Estuary, further indicating that night-time isoprene emission should be considered in aquatic models of isoprene flux. Dani et al. (2020) demonstrated the ability of mixotrophic Chlorella vulgaris to produce isoprene in the dark only while supplied with glucose, thus a contribution to aquatic isoprene production by mixotrophic protists growing heterotrophically should be considered. Gantt et al. (2009), however, reported that certain diatom and coccolithophore species did not produce any significant quantity of isoprene when incubated in the dark.

Isoprene production was reported in laboratory cultures of coral-associated dinoflagellates, such as Symbiodiniaceae (Exton et al. 2013). Also, field data from Indonesia suggested that BVOC production by coral holobionts exceeded that of other primary producers such as macroalgae and seagrasses (Exton et al. 2015). Isoprene-degrading capacity was demonstrated in tropical coastal seawater microcosms (Acuña Alvarez et al. 2009), and isoprene production by the coral Acropora aspera was confirmed by Swan et al. (2016). Isoprene emissions were highest when corals were stressed by agitation caused by shaking, coinciding with the release of mucus. Conversely, isoprene was not detected, and mucus was not produced, when $A$. aspera fragments were undisturbed. Symbiodiniaceae that associate with the gastrodermis of the coral host were suspected as the primary source of isoprene, although this was not investigated. Under stressful conditions, such as elevated temperature or light intensity, coral hosts exude their zooxanthellae symbionts, which are secreted via mucus sloughing (Broadbent \& Jones 2004). A. aspera inhabits shallow bodies of water, such as reef flats and lagoons, making this species particularly susceptible to solar irradiance. This stress is thought to induce production of VOCs including DMS and isoprene by coral-associated zooxanthellae and may result in mucus production by the coral host (Swan et al. 2016).

Since comprehensive data on isoprene production by corals are lacking, for this work we conducted experiments with $A$. horrida coral fragments using a static headspace sampling method. A. horrida fragments produced isoprene at a mean rate of $0.97 \pm$ 0.12 and $2.24 \pm 0.89 \mathrm{pmol} \mathrm{cm}^{-2} \mathrm{~h}^{-1}$ during incubations at 27 and $29^{\circ} \mathrm{C}$, respectively (Fig. 5). Isoprene production rates were significantly different between temperature regimes $(\mathrm{p} \leq 0.05)$, determined by 1 -way ANOVA, suggesting that isoprene is involved in a thermo-protective response by $A$. horrida. Cropp et al. (2018) suggested that corals may emit BVOCs in response to stressors such as irradiance, indicating that the relationship between isoprene emission and coral stress requires further investigation. Isoprene production by Acropora spp. suggested that scleractinian coral holobionts are important isoprene producers in tropical marine regions and contribute to the total atmospheric flux of isoprene from the marine environment. However, compared to isoprene emissions from microalgae (Colomb et al. 2008, Bonsang et al. 2010, Exton et al. 2013) and macroalgae (Broadgate et al. 2004) the measurements reported 


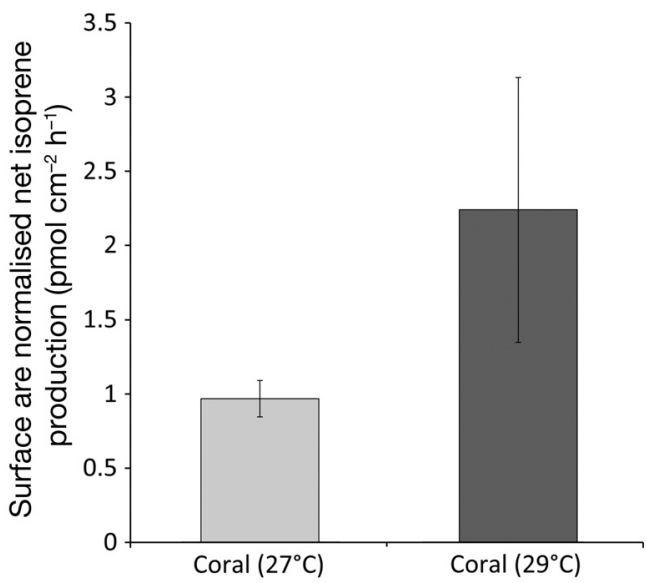

Fig. 5. Isoprene production by Acropora horrida coral fragments incubated at $27^{\circ} \mathrm{C}(\mathrm{n}=8)$ and $29^{\circ} \mathrm{C}(\mathrm{n}=3)( \pm \mathrm{SE})$, normalised by surface area. Coral fragments were incubated for $4 \mathrm{~h}$ in $100 \mathrm{ml}$ gas-tight bottles containing purged artificial seawater and exposed to a light intensity of $300 \mu \mathrm{mol}$ photons $\mathrm{m}^{-2} \mathrm{~s}^{-1}$. Control bottles containing only purged artificial seawater were incubated under the same conditions. Coral isoprene production was control-corrected by subtracting control-bottle isoprene concentrations from isoprene concentrations measured in bottles containing coral fragments. Using the purge-and-trap method, isoprene was measured via a Shimadzu GC-2014 gas chromatograph coupled with a flame ionisation detector (GC-FID). The GC column was a 1.5 m glass column packed with $10 \%$ Apiezon L on CarboWax (60/80 mesh). The statistical test performed on these data was 1-way ANOVA

here for A. horrida are lower. The data presented here represent the emission of isoprene by $A$. horrida normalised per unit of surface area. A. horrida has a large surface area relative to its 2-dimensional footprint. Hence, per sea surface area, coral reefs may add substantially to local isoprene emissions. Additionally, while Swan et al. (2016) primarily attributed isoprene emissions from $A$. aspera to the symbiotic zooxanthellae, Raina et al. (2013) found that Acropora spp. produced dimethylsulfoniopropionate (DMSP) even in the absence of Symbiodiniaceae symbionts, indicating the possibility that the coral host may be responsible for the emission of other BVOC. Lawson et al. (2020) also recently reported significant changes to the output of BVOCs from Symbiodiniaceaeassociated bacteria when incubated with filtrate derived from the phytoplankton, indicating a role of bacteria in the emission of BVOCs from corals, although this has not been linked to isoprene. The impact of changing environmental conditions on isoprene emission by coral requires further study. A. aspera emits isoprene under ambient conditions (Swan et al. 2016), and no significant difference in isoprene emission by A. intermedia or Pocillopora damicornis occurred in response to acute heat stress
(Lawson et al. 2021). The contribution of other coral species, particularly those belonging to more thermally tolerant genera such as Porites spp. (Loya et al. 2001), must be investigated further.

Hrebien et al. (2020) reported that coral reefs with a covering of microphytobenthos at Heron Island (southern Great Barrier Reef) generated isoprene at rates between 194.4 and $290.4 \mathrm{nmol} \mathrm{m}^{-2} \mathrm{~d}^{-1}$ (Table 1), whereas reef sediments at Lizard Island on the northern end of the Great Barrier Reef generated between 69.6 and $139.2 \mathrm{nmol} \mathrm{m}{ }^{-2} \mathrm{~d}^{-1}$. The difference in production was suggested to be due to differences in the composition of the local benthic communities (Hrebien et al. 2020). The greatest values for isoprene flux were recorded during the daytime, while night-time values became negative at times. Fluxes of $-1.5 \pm 1.0$ to $4.8 \pm 0.8 \mathrm{nmol} \mathrm{m}^{-2} \mathrm{~h}^{-1}$ at Heron Island and $1.2 \pm 6.1$ to $2.6 \pm 0.2 \mathrm{nmol} \mathrm{m}^{-2} \mathrm{~h}^{-1}$ at Lizard Island were recorded in the dark, respectively (Hrebien et al. 2020), suggesting that these carbonate sediments and their associated microphytobenthos may become sources or sinks for isoprene according to a diel cycle.

\section{MECHANISMS OF ISOPRENE LOSS FROM AQUATIC ECOSYSTEMS}

Mechanisms of isoprene loss from the ocean are poorly understood, although the greatest loss is likely to be due to abiotic processes such as air-sea gas exchange, driven by wind-speed and local temperature (Palmer \& Shaw 2005, Booge et al. 2018). Bacteria were suggested to be the second most important cause of isoprene loss (Palmer \& Shaw 2005). Reports have also suggested the importance of reactive oxygen species (ROS) and hydoxyl radicals $(\mathrm{OH})$ in the aqueous phase, also important in atmospheric cycling of isoprene (Seinfeld \& Pandis 2006, Wennberg et al. 2018, Berndt et al. 2019), although the turnover of these processes in the ocean has not been fully described (Riemer et al. 2000, Palmer \& Shaw 2005, Zinser 2018). The role of isoprene-degrading microorganisms in marine ecosystems has yet to be quantified. Booge et al. (2018) emphasised that calculations of isoprene loss, aside from abiotic processes such as air-sea exchange, must include microbial metabolism. They reported rate-loss constants for microorganisms in equatorial and coastal regions of 0.01 and $0.1 \mathrm{~d}^{-1}$, respectively, indicating greater microbial activity in productive coastal zones, although total bacterial cell numbers did not significantly influence the rate of consumption (Booge et al. 2018). Factors that influence bacterial community composition must 
also be considered. Areas with a high abundance of grazers of haptophytes, a phytoplankton functional type which is also responsible for emission of isoprene (Table 2), may remove the correlation between bacterial abundance and local aquatic isoprene concentration (noted by Booge et al. 2018).

Intertidal waters and sediments, including almost fresh, brackish and marine waters, were the subject of some of the first studies into the identification of aquatic isoprene-degraders. Isoprene-enriched microcosms from water in the Colne Estuary (UK) were dominated by Mycobacterium (approximately $90 \%$ relative abundance), with a small contribution by Ochrobacterium closer to the mouth of the estuary (Acuña Alvarez et al. 2009). Isoprene-enriched microcosms from sediments taken from the same locations were dominated by Rhodococcus spp. (approximately $65-70 \%$ ), with smaller contributions by Actinosynnema (Acuña Alvarez et al. 2009). Isoprene-enriched sediments and waters from the Berre Lagoon (southern France) were both dominated by Rhodococcus spp. (80-93\% relative abundance), unlike the Colne Estuary in which Rhodococcus spp. were only detected in the sediments (Acuña Alvarez et al. 2009). Isoprene-enriched taxa were linked to the function of isoprene degradation by DNA-SIP. For example, Actinobacteria were the most abundant isoprene-degrading bacteria from the Colne Estuary (Johnston et al. 2017). Members of this phylum have been linked to isoprene degradation in previous studies of freshwater (sediment and water), as well as terrestrial leaves and soils, with Rhodococcus spp. frequently dominating isoprene-enriched communities (Acuña Alvarez et al. 2009, Carrión et al. 2018, Crombie et al. 2018, Larke-Mejía et al. 2019). Rhodococcus sp. AD45, the basis for several studies of the mechanisms of isoprene degradation, was initially isolated from freshwater sediment (van Hylckama Vlieg et al. 1998).

Isoprene-degrading bacteria have been enriched and isolated from marine ecosystems. Acuña Alvarez et al. (2009) reported that the microbial community of isoprene-enriched Indonesian seawater was dominated by Stappia spp. (62\% relative abundance), with a significant contribution from Rhodococcus spp. (31\% relative abundance). Stappia sp. Il2 was also isolated from seawater in the Western Channel, UK (Johnston et al. 2017), indicating the ability of isoprene-degraders from this genus to inhabit environmentally distinct marine ecosystems. Acuña Alvarez et al. (2009) also reported that isoprene produced by Dunaliella tertiolecta and Phaeodactylum tricornutum was consumed at environmentally relevant con- centrations, by a mixture of isoprene-degrading bacteria isolated from estuarine sources. They noted that these concentrations did not support the proliferation of these bacteria but that the cell density initially increased in response to isoprene exposure, suggesting that the nutritional versatility of isoprenedegraders was important to their lifestyle. This versatility was supported by Moore et al. (2020), who noted an increase in intracellular ATP in Pelagibacter sp. HTCC1062 (SAR11) when supplemented with isoprene. Interestingly, when co-cultured with Pelagibacter sp. HTCC1062 (SAR11), the isoprene-emitting Thalassiosira pseudonana displayed a $20 \%$ increase in carbon fixation due to VOC removal by the bacterium (Moore et al. 2020).

Although few studies are available that demonstrate isoprene degradation by marine microbial communities, the role of microorganisms as a marine isoprene sink has already been suggested (Moore \& Wang 2006, Davie-Martin et al. 2020). The isoprene oxidation capacity of microbes associated with corals has also not been tested, and so we measured isoprene degradation in serum bottles containing either ground coral fragments or bacterial cells filtered from aquarium seawater in which the corals were growing (Fig. 6). Compared with the sterile controls, biodegradation of isoprene was clearly demonstrated in both sample types. Irrespective of the incubation temperature, isoprene loss was significantly greater after $22 \mathrm{~d}$ in the ground-coral incubations than in incubations with planktonic cells concentrated onto filters $(p<0.01)$. Data were analysed for statistical significance by the repeated measures ANOVA. Thus, the isoprene-enriched microenvironment associated with the coral holobiont may facilitate the establishment of an isoprene-degrading community, resulting in the observed differences in degradation rates between coral fragments and planktonic bacterial cells. These findings also suggest that gross isoprene production by $A$. horrida is likely to be considerably higher than net production identified in Table 3 and, in the absence of isoprene-degrading microorganisms, that coralsourced isoprene could have a larger impact on atmospheric chemistry, particularly at a local scale.

\section{FUTURE PERSPECTIVES}

Very few reports of isoprene emission and flux are available from aquatic ecosystems, particularly freshwater, adding to the uncertainty in estimates of global aquatic isoprene cycling. The disparity between top-down and bottom-up measurements of 


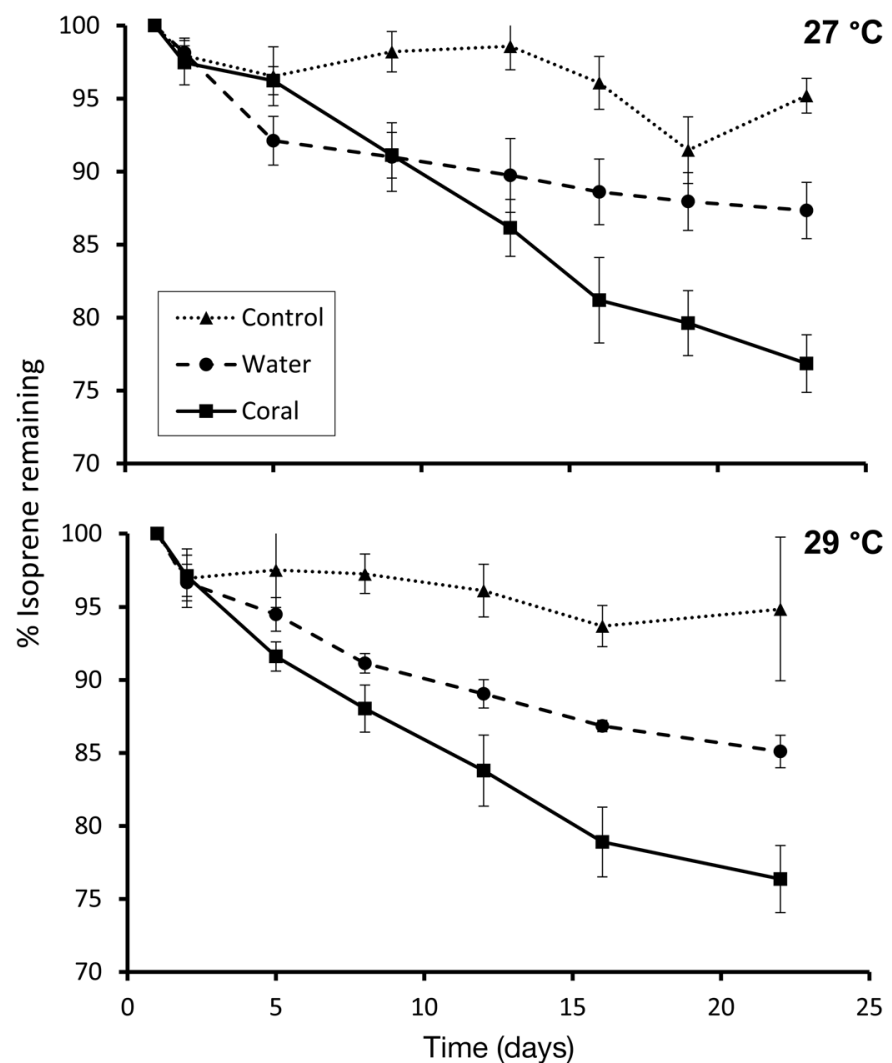

Fig. 6. Microbial isoprene degradation in serum bottles (125 ml) containing ground Acropora horrida coral fragments or $0.22 \mu \mathrm{M}$ filters containing aquarium water-associated bacterial cells $\left( \pm\right.$ SE). Following incubation at 27 or $29^{\circ} \mathrm{C}$, coral fragments $\left(0.43 \pm 0.14 \mathrm{~g}, 27^{\circ} \mathrm{C} ; 0.34 \pm 0.07 \mathrm{~g}, 29^{\circ} \mathrm{C}\right)$ were ground into a course powder using a sterile pestle and mortar and added to serum bottles containing $10 \mathrm{ml}$ of ONR7a seawater-nutrient medium (Dyksterhouse et al. 1995). Gasphase isoprene $(100 \mu \mathrm{l})$, taken from the headspace of liquid isoprene ( $\geq 99 \%$ purity), was injected into each bottle. Aquarium water $(300 \mathrm{ml})$, maintained at 27 or $29^{\circ} \mathrm{C}$, was filtered through $0.22 \mu \mathrm{M}$ filters to collect bacterial cells. A single filter was added to each serum bottle containing $10 \mathrm{ml}$ of ONR7a seawater-nutrient medium and enriched with $100 \mu \mathrm{l}$ of gas-phase isoprene. No-inoculum controls $(n=6)$ were prepared by injecting $100 \mu \mathrm{l}$ of gas-phase isoprene into serum bottles containing $10 \mathrm{ml}$ of ONR7a seawater-nutrient medium only. Serum bottles were incubated in the dark at $30^{\circ} \mathrm{C}$. Headspace isoprene concentrations were measured using an ATI Unicam 610 Series gas chromatograph with a $1.5 \mathrm{~m}$ packed column $(10 \%$ Apiezon L on CarboWax, 60-80 mesh) and a flame ionisation detector

marine isoprene emissions demonstrates the need for an improved understanding of the factors controlling isoprene cycling (Arnold et al. 2009, Luo \& Yu 2010, $\mathrm{Hu}$ et al. 2013). Exceptions to the typical diel cycle of isoprene emission must also be studied. Exton et al. (2012) identified 2 distinct peaks in isoprene concentration in the daytime and night-time in the Colne Estuary, and cyanobacteria and diatoms also retain a portion of the daytime rate of isoprene emission while in the dark (Shaw et al. 2003, Ooki et al. 2019). The freshwater mixotroph, Chlorella vulgaris, produced isoprene at the same rate irrespective of whether it was grown as a photoautotroph under light or as a heterotroph feeding on exogenous glucose in the dark (Dani et al. 2020). It will be interesting to determine the contribution of mixotrophic marine protists to dark isoprene production, especially in the oligotrophic ocean. Moreover, some terrestrial heterotrophic bacteria produce isoprene (Kuzma et al. 1995), so their contribution to dark isoprene production in the aquatic environment merits investigation. There is a need for in situ measurements of isoprene emissions (Palmer \& Shaw 2005, Conte et al. 2020) over a wider range of marine environments and time scales, and for an improved understanding of the difference in emission rates between different phytoplankton functional types (PFTs) (Booge et al. 2016, 2018, Dani et al. 2017, Conte et al. 2020). This requirement is evident when considering the differences in isoprene emission reported by Exton et al. (2013). Marine microalgae of the classes Chlorophyceae and Dinophyceae produced isoprene at rates of 0.05 and 0.86 $\mu \mathrm{mol}$ ( $\mathrm{g} \mathrm{chl} \mathrm{a}$ ) $\mathrm{h}^{-1}$, respectively, indicating that the local composition of the phytoplankton community can cause wide variations in emission rates (Exton et al. 2013, Booge et al. 2016). The need for a greater range of emission data from different phytoplankton functional types has been identified by recent studies (Booge et al. 2018, Conte et al. 2020).

There is very little information available regarding the community composition or abundance of isoprenedegraders in marine ecosystems. Given the significant increases in dissolved and emitted isoprene during phytoplankton blooms (Moore \& Wang 2006, Ooki et al. 2019, Davie-Martin et al. 2020, Tripathi et al. 2020), blooming events may trigger seasonal changes in microbial isoprene-degrading communities. Systematic surveys of these communities using functional gene probes would begin to identify the interactions between isoprene-emitting and isoprene-degrading microorganisms in aquatic ecosystems. Previous studies used specifically designed probes to target the conserved active site component of isoprene monooxygenase (isoA) in the isoprene metabolic pathway (El Khawand et al. 2016, Carrión et al. 2018). Thus far, only the 16S rRNA gene has been used to distinguish between isoprene-enriched microcosms from estuarine, freshwater, and marine waters and sediments (Acuña Alvarez et al. 2009). Studies using the 16S rRNA gene primarily identified members of the Actinobacteria and Alphaproteobacteria (Acuña Alvarez 
et al. 2009, Johnston et al. 2017). Further studies using isoA-specific probes are required, as this would begin to reveal the distribution, diversity, and abundance of isoprene-degraders in aquatic samples. The interface between aquatic and terrestrial ecosystems also requires further study, as isoprene emissions from terrestrial sources may influence aquatic isoprenedegrading bacteria, and vice versa. Inland aquatic ecosystems such as estuarine water and sediments, rivers, and also partially submerged vegetation such as mangrove swamps may provide valuable insights into the interplay between aquatic and terrestrial isoprene sources and sinks. Given that lakes constitute a large surface area in northern latitudes, their contribution to isoprene production merits further investigation, especially in areas of the Arctic where warming is most rapid.

Additional isolates of aquatic isoprene-degrading bacteria are required in order to conduct further laboratory-based studies. At present, isoA serves as the basis for molecular probing of isoprene-degrading communities, but this does not account for alternative metabolic pathways. A recent study by Kronen et al. (2019) demonstrated anaerobic metabolism of isoprene, with isoprene acting as an electron acceptor, highlighting the need for a broader understanding of the diversity of isoprene-utilising microorganisms. The majority of isolated isoprene oxidisers are terrestrial, with the few aquatic isolates sharing the archetypal isoprene metabolic pathway first described in Rhodococcus sp. AD45 (van Hylckama Vlieg et al. 2000). Aside from bona fide isoprene-degraders, some SDIMO are able to catalyse the co-oxidation of isoprene to epoxyisoprene without its subsequent incorporation as a source of carbon or energy. Such SDIMO include the sMMO of Methylococcus capsulatus (Bath) (Colby et al. 1977, Green \& Dalton 1989, Dawson et al. 2020) and the 4-component alkene monooxygenase of Xanthobacter autotrophicus Py2 (Small \& Ensign 1997, Ensign 2001, Johnston et al. 2017). A recent study demonstrated the use of inhibitory linear alkynes to differentiate between isoprene oxidation by the bona fide isoprene-degrader Variovorax sp. WS11 and the methanotroph M. capsulatus (Bath), wherein acetylene specifically inhibited co-oxidation by the sMMO and octyne specifically inhibited the isoprene monooxygenase (Dawson et al. 2020). This approach could be used to interrogate the active isoprene-degrading communities of various environmental samples. Co-oxidation of isoprene may facilitate cross-feeding of unrelated microorganisms in aquatic ecosystems, which has frequently posed an issue for DNA-SIP studies (Mooshammer et al. 2021). Meta-metabolomics analysis would provide valuable insights into the contributions of isoprenedegrading and co-oxidising microorganisms. At the laboratory scale, this could begin with co-culture work similar to that described by Acuña Alvarez et al. (2009) and Moore et al. (2020). By using labelled $\mathrm{CO}_{2}$, the flow of carbon could be tracked between isoprene-emitting phytoplankton and isoprene-consuming organisms. Isoprene metabolism may not be limited to bacteria; to date there have been no reports of archaeal or fungal isoprene-degraders, although the abundance of the Zygomycota increased during incubations with isoprene in a soil study (Gray et al. 2015). On a broader scale, a combination of omics techniques performed on water and sediment from diverse locations would further clarify the biological underpinnings of isoprene cycling in aquatic environments.

Acknowledgements. J.C.M., A.T.C. and R.A.D. were funded through a European Research Council Advanced Grant (IsoMET 694578) to J.C.M. We acknowledge funding through a Natural Environment Research Council grant to J.C.M. (NE/J009725/1) and T.J.M. (NE/J009555/1) and funding via the Earth and Life Systems Alliance (ELSA) at the University of East Anglia. We also acknowledge the award of a Leverhulme Trust Early Career Fellowship (ECF-2016-626) to A.T.C. We thank Russell Smart, Farid Benyahia and John Green for their technical support.

\section{LITERATURE CITED}

Acuña Alvarez L, Exton DA, Timmis KN, Suggett DJ, McGenity TJ (2009) Characterization of marine isoprenedegrading communities. Environ Microbiol 11:3280-3291

Alvain S, Moulin C, Dandonneau Y, Bréon FM (2005) Remote sensing of phytoplankton groups in case 1 waters from global SeaWiFS imagery. Deep Sea Res I 52: 1989-2004

Arnold SR, Spracklen DV, Williams J, Yassaa N and others (2009) Evaluation of the global oceanic isoprene source and its impacts on marine organic carbon aerosol. Atmos Chem Phys 9:1253-1262

Atkinson R, Arey J (2003) Atmospheric degradation of volatile organic compounds. Chem Rev 103:4605-4638

* Baker AR, Turner SM, Broadgate WJ, Thompson A and others (2000) Distribution and sea-air fluxes of biogenic trace gases in the eastern Atlantic Ocean. Global Biogeochem Cycles 14:871-886

* Bentlage B, Rogers TS, Bachvaroff TR, Delwiche CF (2016) Complex ancestries of isoprenoid synthesis in dinoflagellates. J Eukaryot Microbiol 63:123-137

Berndt T, Hyttinen N, Herrmann H, Hansel A (2019) First oxidation products from the reaction of hydroxyl radicals with isoprene for pristine environmental conditions. Commun Chem 2:1-10

Bonsang B, Polle C, Lambert G (1992) Evidence for marine production of isoprene. Geophys Res Lett 19:1129-1132

Bonsang B, Gros V, Peeken I, Yassaaa N and others (2010) Isoprene emission from phytoplankton monocultures: the relationship with chlorophyll-a, cell volume and car- 
bon content. Environ Chem 7:554-563

Booge D, Marandino CA, Schlundt C, Palmer PI and others (2016) Can simple models predict large-scale surface ocean isoprene concentrations? Atmos Chem Phys 16: 11807-11821

Booge D, Schlundt C, Bracher A, Endres S, Zäncker B, Marandino CA (2018) Marine isoprene production and consumption in the mixed layer of the surface ocean - a field study over two oceanic regions. Biogeosciences 15: 649-667

Broadbent AD, Jones GB (2004) DMS and DMSP in mucus ropes, coral mucus, surface films and sediment pore waters from coral reefs in the Great Barrier Reef. Mar Freshw Res 55:849-855

Broadgate WJ, Liss PS, Penkett SA (1997) Seasonal emissions of isoprene and other reactive hydrocarbons from the ocean. Geophys Prospect 24:2675-2678

Broadgate WJ, Malin G, Küpper FC, Thompson A, Liss PS (2004) Isoprene and other non-methane hydrocarbons from seaweeds: a source of reactive hydrocarbons to the atmosphere. Mar Chem 88:61-73

* Brüggemann M, Hayeck N, George C (2018) Interfacial photochemistry at the ocean surface is a global source of organic vapors and aerosols. Nat Commun 9:1-8

Carlton AG, Wiedinmyer C, Kroll JH (2009) A review of secondary organic aerosol (SOA) formation from isoprene. Atmos Chem Phys 9:4987-5005

* Carrión O, Larke-Mejía NL, Gibson L, Farhan Ul Haque M, Ramiro-García J, McGenity TJ, Murrell JC (2018) Gene probing reveals the widespread distribution, diversity and abundance of isoprene-degrading bacteria in the environment. Microbiome 6:219

* Carrión O, Gibson L, Elias DMO, McNamara NP and others (2020a) Diversity of isoprene-degrading bacteria in phyllosphere and soil communities from a high isopreneemitting environment: a Malaysian oil palm plantation. Microbiome 8:81

*arrión O, McGenity TJ, Murrell JC (2020b) Molecular ecology of isoprene-degrading bacteria. Microorganisms 8:967

* Ciuraru R, Fine L, Van Pinxteren M, D'Anna B, Herrmann H, George C (2015) Unravelling new processes at interfaces: photochemical isoprene production at the sea surface. Environ Sci Technol 49:13199-13205

Cleveland C, Yavitt J (1997) Consumption of atmospheric isoprene in soil. Geophys Res Lett 24:2379-2382

* Cleveland CC, Yavitt JB (1998) Microbial consumption of atmospheric isoprene in a temperate forest soil. Appl Environ Microbiol 64:172-177

Colby J, Stirling DI, Dalton H (1977) The soluble methane mono-oxygenase of Methylococcus capsulatus (Bath). Biochem J 165:395-402

Collins WJ, Derwent RG, Johnson CE, Stevenson DS (2002) The oxidation of organic compounds in the troposphere and their global warming potentials. Clim Change 52: 453-479

Colomb A, Yassaa N, Williams J, Peeken I, Lochte K (2008) Screening volatile organic compounds (VOCs) emissions from five marine phytoplankton species by head space gas chromatography/mass spectrometry (HS-GC/MS). J Environ Monit 10:325-330

Conte L, Szopa S, Aumont O, Gros V, Bopp L (2020) Sources and sinks of isoprene in the global open ocean: simulated patterns and emissions to the atmosphere. J Geophys Res Oceans 125
Crombie AT, El Khawand M, Rhodius VA, Fengler KA and others (2015) Regulation of plasmid-encoded isoprene metabolism in Rhodococcus, a representative of an important link in the global isoprene cycle. Environ Microbiol 17:3314-3329

Crombie AT, Larke-Mejia NL, Emery H, Dawson R, Pratscher J, Murphy GP (2018) Poplar phyllosphere harbors disparate isoprene-degrading bacteria. Proc Natl Acad Sci USA 115:13081-13086

Cropp R, Gabric A, van Tran D, Jones G, Swan H, Butler H (2018) Coral reef aerosol emissions in response to irradiance stress in the Great Barrier Reef, Australia. Ambio 47:671-681

Cui T, Green HS, Selleck PW, Zhang Z and others (2019) Chemical characterization of isoprene- and monoterpenederived secondary organic aerosol tracers in remote marine aerosols over a quarter century. ACS Earth Space Chem 3:935-946

* Dani KGS, Loreto F (2017) Trade-off between dimethyl sulfide and isoprene emissions from marine phytoplankton. Trends Plant Sci 22:361-372

ํDani KGS, Silva Benavides AM, Michelozzi M, Peluso G and others (2017) Relationship between isoprene emission and photosynthesis in diatoms, and its implications for global marine isoprene estimates. Mar Chem 189:17-24

Dani KGS, Torzillo G, Michelozzi M, Baraldi R, Loreto F (2020) Isoprene emission in darkness by a facultative heterotrophic green alga. Front Plant Sci 11:598786

Davie-Martin CL, Giovannoni SJ, Behrenfeld MJ, Penta WB, Halsey KH (2020) Seasonal and spatial variability in the biogenic production and consumption of volatile organic compounds (VOCs) by marine plankton in the North Atlantic Ocean. Frontiers (Boulder) 7:1-15

*Dawson RA, Larke-Mejía NL, Crombie AT, Farhan Ul Haque M, Murrell JC (2020) Isoprene oxidation by the Gram-negative model bacterium Variovorax sp. WS11. Microorganisms 8

*Dumont MG, Murrell JC (2005) Stable isotope probing linking microbial identity to function. Nat Rev Microbiol 3:499-504

* Dyksterhouse SE, Gray JP, Herwig RP, Lara JC, Staley JT (1995) Cycloclasticus pugetii gen. nov., sp. nov., an aromatic hydrocarbon-degrading bacterium from marine sediments. Int J Syst Evol Microbiol 45:116-123

*Ekberg A, Arneth A, Hakola H, Hayward S, Holst T (2009) Isoprene emission from wetland sedges. Biogeosciences 6:601-613

Ekberg A, Arneth A, Holst T (2011) Isoprene emission from Sphagnum species occupying different growth positions above the water table. Boreal Environ Res 16:47-59

El Khawand M, Crombie AT, Johnston A, Vavlline DV and others (2016) Isolation of isoprene degrading bacteria from soils, development of isoA gene probes and identification of the active isoprene-degrading soil community using DNA-stable isotope probing. Environ Microbiol 18: 2743-2753

Ensign SA (2001) Microbial metabolism of aliphatic alkenes. Biochemistry 40:5845-5853

Ewers J, Freier-Schröder D, Knackmuss H (1990) Selection of trichloroethene (TCE) degrading bacteria that resist inactivation by TCE. Arch Microbiol 154:410-413

Exton DA, Suggett DJ, Steinke M, McGenity TJ (2012) Spatial and temporal variability of biogenic isoprene emissions from a temperate estuary. Global Biogeochem Cycles 26:1-13 
Exton DA, Suggett DJ, McGenity TJ, Steinke M (2013) Chlorophyll-normalized isoprene production in laboratory cultures of marine microalgae and implications for global models. Limnol Oceanogr 58:1301-1311

Exton DA, McGenity TJ, Steinke M, Smith DJ, Suggett DJ (2015) Uncovering the volatile nature of tropical coastal marine ecosystems in a changing world. Glob Chang Biol 21:1383-1394

Farhan Ul Haque M, Crombie AT, Murrell JC (2019) Novel facultative Methylocella strains are active methane consumers at terrestrial natural gas seeps. Microbiome 7:134

Folberth GA, Hauglustaine DA, Lathière J, Brocheton F (2006) Interactive chemistry in the Laboratoire de Météorologie Dynamique general circulation model: model description and impact analysis of biogenic hydrocarbons on tropospheric chemistry. Atmos Chem Phys 6:2273-2319

Gantt B, Meskhidze N, Kamykowski D (2009) A new physically-based quantification of marine isoprene and primary organic aerosol emissions. Atmos Chem Phys 9: 4915-4927

* Gibson L, Larke-Mejía NL, Murrell JC (2020) Complete genome of isoprene degrading Nocardioides sp. WS12. Microorganisms 8:889

Gray CM, Helmig D, Fierer N (2015) Bacteria and fungi associated with isoprene consumption in soil. Elementa $3: 1-10$

* Green J, Dalton H (1989) Substrate specificity of soluble methane monooxygenase. Mechanistic implications. J Biol Chem 264:17698-17703

Greve HH (2000) Rubber, 2. Natural. Ullmann's Encyclopedia of Industrial Chemistry. Wiley-VCH, Weinheim

* Guenther AB, Hewitt CN, Erickson D, Fall R and others (1995) A global model of natural volatile organic compound emissions. J Geophys Res 100:8873-8892

Guenther AB, Karl T, Harley P, Wiedinmyer C, Palmer PI, Geron C (2006) Estimates of global terrestrial isoprene emissions using MEGAN (Model of Emissions of Gases and Aerosols from Nature). Atmos Chem Phys Discuss 6: 107-173

* Guenther AB, Jiang X, Heald CL, Sakulyanontvittaya T, Duhl T, Emmons LK, Wang X (2012) The model of emissions of gases and aerosols from nature version 2.1 (MEGAN2.1): an extended and updated framework for modeling biogenic emissions. Geosci Model Dev 5: 1471-1492

*Hackenberg SC, Andrews SJ, Airs R, Arnold SR and others (2017) Potential controls of isoprene in the surface ocean. Global Biogeochem Cycles 31:644-662

*Halsey KH, Giovannoni SJ, Graus M, Zhao Y and others (2017) Biological cycling of volatile organic carbon by phytoplankton and bacterioplankton. Limnol Oceanogr 62:2650-2661

Harley P, Deem G, Flint S, Caldwell M (1996) Effects of growth under elevated UV-B on photosynthesis and isoprene emission in Quercus gambelii and Mucuna pruriens. Glob Chang Biol 2:149-154

Kellén H, Schallhart S, Praplan AP, Tykkä T, Aurela M, Lohila A, Hakola H (2020) Sesquiterpenes dominate monoterpenes in northern wetland emissions. Atmos Chem Phys 20:7021-7034

Hewitt CN, MacKenzie AR, Di Carlo P, Di Marco CF and others (2009) Nitrogen management is essential to prevent tropical oil palm plantations from causing groundlevel ozone pollution. Proc Natl Acad Sci USA 106:
$18447-18451$

*Hrebien V, Deschaseaux E, Eyre BD (2020) Isoprene flux from permeable carbonate sediments on the Great Barrier Reef. Mar Chem 225

Hu QH, Xie ZQ, Wang XM, Kang H, He QF, Zhang P (2013) Secondary organic aerosols over oceans via oxidation of isoprene and monoterpenes from Arctic to Antarctic. Sci $\operatorname{Rep~3:2280}$

Hu S, Niu Z, Chen Y (2017) Global wetland datasets: a review. Wetlands 37:807-817

* Janson R, De Serves C (1998) Isoprene emissions from boreal wetlands in Scandinavia. J Geophys Res Atmos 103:25513-25517

Johnson T, Newton GL, Fahey RC, Rawat M (2009) Unusual production of glutathione in Actinobacteria. Arch Microbiol 191:89-93

* Johnston A, Crombie AT, El Khawand M, Sims L, Whited GM, McGenity TJ, Murrell JC (2017) Identification and characterisation of isoprene-degrading bacteria in an estuarine environment. Environ Microbiol 19: 3526-3537

K Kameyama S, Yoshida S, Tanimoto H, Inomata S, Suzuki K, Yoshikawa-Inoue H (2014) High-resolution observations of dissolved isoprene in surface seawater in the Southern Ocean during austral summer. J Oceanogr 70:225-239

K Karlsson T, Rinnan R, Holst T (2020) Variability of BVOC emissions from commercially used willow (Salix spp.) varieties. Atmosphere 11:356

Khan MAH, Schlich BL, Jenkin ME, Shallcross BMA and others (2018) A two-decade anthropogenic and biogenic isoprene emissions study in a London urban background and a London urban traffic site. Atmosphere 9:387

Kröber E, Eyice Ö (2019) Profiling of active microorganisms by stable isotope probing-metagenomics. In: Dumont MG, Hernández García M (eds) Stable isotope probing. Human Press, Totowa, NJ, p 151-161

Kronen M, Lee M, Jones ZL, Manefield MJ (2019) Reductive metabolism of the important atmospheric gas isoprene by homoacetogens. ISME J 13:1168-1182

Kumar S, Stecher G, Tamura K (2016) MEGA7: molecular evolutionary genetics analysis version 7.0 for bigger datasets. Mol Biol Evol 33:1870-1874

Kuzma J, Nemecek-Marshall M, Pollock WH, Fall R (1995) Bacteria produce the volatile hydrocarbon isoprene. Curr Microbiol 30:97-103

ㄴLantz AT, Allman J, Weraduwage S, Sharkey TD (2019) Isoprene: new insights into the control of emission and mediation of stress tolerance by gene expression. Plant Cell Environ 42:2808-2826

*Larke-Mejía NL, Crombie AT, Pratscher J, McGenity TJ, Murrell JC (2019) Novel isoprene-degrading proteobacteria from soil and leaves identified by cultivation and metagenomics analysis of stable isotope probing experiments. Front Microbiol 10:2700

* Larke-Mejía NL, Carrión O, Crombie AT, McGenity TJ, Murrell JC (2020) Sphingopyxis sp. strain OPL5, an isoprene-degrading bacterium from the Sphingomonadaceae family isolated from oil palm leaves. Microorganisms 8:1557

Lawson CA, Seymour JR, Possell M, Suggett DJ, Raina JB (2020) The volatilomes of Symbiodiniaceae-associated bacteria are influenced by chemicals derived from their algal partner. Front Mar Sci 7:106

Lawson CA, Raina JB, Deschaseaux E, Hrebien V, Possell M, Seymour JR, Suggett DJ (2021) Heat stress decreases 
the diversity, abundance and functional potential of coral gas emissions. Glob Change Biol 27:879-891

Leahy JG, Batchelor PJ, Morcomb SM (2003) Evolution of the soluble diiron monooxygenases. FEMS Microbiol Rev 27:449-479

Li JL, Kameyama S, Yang GP (2020) In-situ measurement of trace isoprene and dimethyl sulfide in seawater and oceanic atmosphere based on room temperature adsorption-thermal desorption. Mar Chem 222:103787

Li Z, Sharkey TD (2013) Metabolic profiling of the methylerythritol phosphate pathway reveals the source of post-illumination isoprene burst from leaves. Plant Cell Environ 36:429-437

Liakakou E, Vrekoussis M, Bonsang B, Donousis C, Kanakidou M, Mihalopoulos N (2007) Isoprene above the Eastern Mediterranean: seasonal variation and contribution to the oxidation capacity of the atmosphere. Atmos Environ 41:1002-1010

Lindwall F, Svendsen SS, Nielsen CS, Michelsen A, Rinnan $\mathrm{R}$ (2016) Warming increases isoprene emissions from an arctic fen. Sci Total Environ 553:297-304

Liss PS, Merlivat L (1986) Air-sea gas exchange rates: introduction and synthesis. In: Buat-Ménard P (ed) The role of air-sea exchange in geochemical cycling. Springer Netherlands, Dordrecht, p 113-127

Lohr M, Schwender J, Polle JEW (2012) Isoprenoid biosynthesis in eukaryotic phototrophs: a spotlight on algae. Plant Sci 185-186:9-22

Loya Y, Sakai K, Yamazato K, Nakano Y, Sambali H, van Woesik R (2001) Coral bleaching: the winners and the losers. Ecol Lett 4:122-131

Luo G, Yu F (2010) A numerical evaluation of global oceanic emissions of $\alpha$-pinene and isoprene. Atmos Chem Phys 10

* Matsunaga S, Mochida M, Saito T, Kawamura K (2002) In situ measurement of isoprene in the marine air and surface seawater from the western North Pacific. Atmos Environ 36:6051-6057

McGenity TJ, Crombie AT, Murrell JC (2018) Microbial cycling of isoprene, the most abundantly produced biological volatile organic compound on Earth. ISME J 12: 931-941

Meskhidze N, Nenes A (2007) Phytoplankton and cloudiness in the Southern Ocean. Science 314:1419-1423

*Meskhidze N, Sabolis A, Reed R, Kamykowski D (2015) Quantifying environmental stress-induced emissions of algal isoprene and monoterpenes using laboratory measurements. Biogeosciences 12:637-651

Milne PJ, Riemer DD, Zika RG, Brand LE (1995) Measurement of vertical distribution of isoprene in surface seawater, its chemical fate, and its emission from several phytoplankton monocultures. Mar Chem 48:237-244

Misztal PK, Nemitz E, Langford B, Di Marco CF and others (2011) Direct ecosystem fluxes of volatile organic compounds from oil palms in South-East Asia. Atmos Chem Phys 11:8995-9017

Monson RK, Winkler B, Rosenstiel TN, Block K and others (2020) High productivity in hybrid-poplar plantations without isoprene emission to the atmosphere. Proc Natl Acad Sci USA 117:1596-1605

Moore ER, Davie-Martin CL, Giovannoni SJ, Halsey KH (2020) Pelagibacter metabolism of diatom-derived volatile organic compounds imposes an energetic tax on photosynthetic carbon fixation. Environ Microbiol 22: 1720-1733
Moore RM, Wang L (2006) The influence of iron fertilization on the fluxes of methyl halides and isoprene from ocean to atmosphere in the SERIES experiment. Deep Sea Res II 53:2398-2409

*Mooshammer M, Kitzinger K, Schintlmeister A, Ahmerkamp S, Nielsen JL, Nielsen PH, Wagner M (2021) Flowthrough stable isotope probing (Flow-SIP) minimizes cross-feeding in complex microbial communities. ISME J 15:348-353

*Murrell JC, McGenity TJ, Crombie AT (2020) Microbial metabolism of isoprene: a much-neglected climate-active gas. Microbiology 166:600-613

Niinemets Ü, Sun Z (2015) How light, temperature, and measurement and growth $\left[\mathrm{CO}_{2}\right]$ interactively control isoprene emission in hybrid aspen. J Exp Bot 66:841-851

Foki A, Nomura D, Nishino S, Kikuchi T, Yokouchi Y (2015) A global-scale map of isoprene and volatile organic iodine in surface seawater of the Arctic, Northwest Pacific, Indian, and Southern Oceans. J Geophys Res Oceans 120:4108-4128

Ooki A, Shida R, Otsu M, Onishi H and others (2019) Isoprene production in seawater of Funka Bay, Hokkaido, Japan. J Oceanogr 75:485-501

Palmer PI, Shaw SL (2005) Quantifying global marine isoprene fluxes using MODIS chlorophyll observations. Geophys Res Lett 32:1-5

* Patel RN, Hou CT, Laskin AI, Felix A (1982) Microbial oxidation of hydrocarbons: properties of a soluble methane monooxygenase from a facultative methane-utilizing organism, Methylobacterium sp. strain CRL-26. Appl Environ Microbiol 44:1130-1137

* Raina JB, Tapiolas DM, Forêt S, Lutz A and others (2013) DMSP biosynthesis by an animal and its role in coral thermal stress response. Nature 502:677-680

* Rasulov B, Copolovici L, Laisk A, Niinemets Ü (2009) Postillumination isoprene emission: in vivo measurements of dimethylallyldiphosphate pool size and isoprene synthase kinetics in aspen leaves. Plant Physiol 149: 1609-1618

* Reimann S, Calanca P, Hofer P (2000) The anthropogenic contribution to isoprene concentrations in a rural atmosphere. Atmos Environ 34:109-115

* Riemer DD, Milne PJ, Zika RG, Pos WH (2000) Photoproduction of nonmethane hydrocarbons (NMHCs) in seawater. Mar Chem 71:177-198

*Rinnan R, Steinke M, McGenity T, Loreto F (2014) Plant volatiles in extreme terrestrial and marine environments. Plant Cell Environ 37:1776-1789

Rodríguez-Ros P, Cortés P, Robinson CM, Nunes S and others (2020) Distribution and drivers of marine isoprene concentration across the Southern Ocean. Atmosphere 11:556

Rohmer M (1999) The discovery of a mevalonate-independent pathway for isoprenoid biosynthesis in bacteria, algae and higher plants. Nat Prod Rep 16:565-574

Seco R, Holst T, Matzen MS, Westergaard-Nielsen A and others (2020) Volatile organic compound fluxes in a subarctic peatland and lake. Atmos Chem Phys 20:13399-13416

Seinfeld JH, Pandis SN (2006) Atmospheric chemistry and physics: from air pollution to climate change, $2^{\text {nd }}$ edn. John Wiley \& Sons, Hoboken, NJ

Sharkey TD, Yeh S (2001) Isoprene emission from plants. Annu Rev Plant Physiol Plant Mol Biol 52:407-436

Sharkey TD, Chen X, Yeh S (2001) Isoprene increases thermotolerance of fosmidomycin-fed leaves. Plant Physiol 125:2001-2006 
Sharkey TD, Wiberley AE, Donohue AR (2008) Isoprene emission from plants: Why and how. Ann Bot 101:5-18

Shaw SL, Chisholm SW, Prinn RG (2003) Isoprene production by Prochlorococcus, a marine cyanobacterium, and other phytoplankton. Mar Chem 80:227-245

Shaw SL, Gantt B, Meskhidze N (2010) Production and emissions of marine isoprene and monoterpenes: a review. Adv Meteorol 2010:1-24

Sims L (2020) Purification and characterisation of isoprene monooxygenase from Rhodococcus sp. AD45. University of East Anglia, Norwich

Singh A, Srivastava N, Dubey SK (2019) Molecular characterization and kinetics of isoprene degrading bacteria. Bioresour Technol 278:51-56

Singsaas EL, Lerdau M, Winter K, Sharkey TD (1997) Isoprene increases thermotolerance of isoprene-emitting species. Plant Physiol 115:1413-1420

Small FJ, Ensign SA (1997) Alkene monooxygenase from Xanthobacter strain Py2. J Biol Chem 272:24913-24920

Srivastva N, Shukla AK, Singh RS, Upadhyay SN, Dubey SK (2015) Characterization of bacterial isolates from rubber dump site and their use in biodegradation of isoprene in batch and continuous bioreactors. Bioresour Technol 188:84-91

Steinke M, Hodapp B, Subhan R, Bell TG, MartinCreuzburg D (2018) Flux of the biogenic volatiles isoprene and dimethyl sulfide from an oligotrophic lake. Sci Rep 8:630

Swan HB, Crough RW, Vaattovaara P, Jones GB and others (2016) Dimethyl sulfide and other biogenic volatile organic compound emissions from branching coral and reef seawater: potential sources of secondary aerosol over the Great Barrier Reef. J Atmos Chem 73:303-328

Trainer M, Williams E, Parrish D, Buhr M, Allwine E, Westberg $H$, Fehsenfeld F (1987) Models and observations of the impact of natural hydrocarbons on rural ozone. Nature 329:705-707

Tran S, Bonsang B, Gros V, Peeken I, Sarda-Esteve R, Bernhardt A, Belviso S (2013) A survey of carbon monoxide and non-methane hydrocarbons in the Arctic Ocean during summer 2010. Biogeosciences 10:1909-1935

Tripathi N, Sahu LK, Singh A, Yadav R, Karati KK (2020) High levels of isoprene in the marine boundary layer of the Arabian Sea during spring inter-monsoon: role of phytoplankton blooms. ACS Earth Space Chem 4: 583-590

Van Ginkel CG, De Jong E, Tilanus JWRR, De Bont JAMM, De Jong E (1987) Microbial oxidation of isoprene, a biogenic foliage volatile and of 1,3-butadiene, an anthropogenic gas. FEMS Microbiol Lett 45:275-279

van Hylckama Vlieg JE, Kingma J, van den Wijngaard A, Janssen D (1998) A glutathione S-transferase with activity towards cis-1,2-dichloroepoxyethane is involved in isoprene utilization by Rhodococcus sp. strain AD45. Appl Environ Microbiol 64:2800-2805

Editorial responsibility: Paul del Giorgio, Montreal, Quebec, Canada, and Hans-Peter Grossart, Neuglobsow, Germany Reviewed by: O. Eyice-Broadbent, K. Halsey and 1 anonymous referee van Hylckama Vlieg JET, Leemhuis H, Jeffrey H, Spelberg L, Janssen DB (2000) Characterization of the gene cluster involved in isoprene metabolism in Rhodococcus sp. strain AD45. J Bacteriol 182(7):1956-1963

* Velikova V, Várkonyi Z, Szabó M, Maslenkova L and others (2011) Increased thermostability of thylakoid membranes in isoprene-emitting leaves probed with three biophysical techniques. Plant Physiol 157:905-916

* Vickers CE, Gershenzon J, Lerdau MT, Loreto F (2009) A unified mechanism of action for volatile isoprenoids in plant abiotic stress. Nat Chem Biol 5:283-291

*Weise SE, Li Z, Sutter AE, Corrion A, Banerjee A, Sharkey TD (2013) Measuring dimethylallyl diphosphate available for isoprene synthesis. Anal Biochem 435:27-34

*Wen J, Zhao Y, Wexler AS (2006) Marine particle nucleation: observation at Bodega Bay, California. J Geophys Res Atmos 111:1-11

Wennberg PO, Bates KH, Crounse JD, Dodson LG and others (2018) Gas-phase reactions of isoprene and its major oxidation products. Chem Rev 118:3337-3390

Wik M, Varner RK, Anthony KW, MacIntyre S, Bastviken D (2016) Climate-sensitive northern lakes and ponds are critical components of methane release. Nat Geosci 9: 99-105

Wu YC, Li JL, Wang J, Zhuang J and others (2021) Occurrance, emission and environmental effects of nonmethane hydrocarbons in the Yellow Sea and the East China Sea. Environ Pollut 270:116305

Xu Q, Yang L, Yang W, Bai Y and others (2017) Volatile organic compounds released from Microcystis flosaquae under nitrogen sources and their toxic effects on Chlorella vulgaris. Ecotoxicol Environ Saf 135:191-200

* Zhao L, Chang WW, Xiao Y, Liu HH, Liu P (2013) Methylerythritol phosphate pathway of isoprenoid biosynthesis. Annu Rev Biochem 82:497-530

* Zindler C, Marandino C, Bange H, Schütte F, Saltzman E (2014) Nutrient availability determines dimethyl sulfide and isoprene distribution in the eastern Atlantic Ocean. Geophys Res Lett 41:3181-3188

Zinser ER (2018) The microbial contribution to reactive oxygen species dynamics in marine ecosystems. Environ Microbiol Rep 10:412-427

*uo Z (2019) Why algae release volatile organic compounds - the emission and roles. Front Microbiol 10:491

* Zuo Z, Zhu Y, Bai Y, Wang Y (2012a) Acetic acid-induced programmed cell death and release of volatile organic compounds in Chlamydomonas reinhardtii. Plant Physiol Biochem 51:175-184

Zuo ZJ, Zhu YR, Bai YL, Wang Y (2012b) Volatile communication between Chlamydomonas reinhardtii cells under salt stress. Biochem Syst Ecol 40:19-24

Zuo Z, Weraduwage SM, Lantz AT, Sanchez LM and others (2019) Isoprene acts as a signaling molecule in gene networks important for stress responses and plant growth. Plant Physiol 180:124-152

Submitted: January 27, 2021

Accepted: May 5, 2021

Proofs received from author(s): June 29, 2021 